\title{
Do Patent Licensing Demands Mean Innovation?
}

\author{
Robin Feldman* E Mark A. Lemley**
}

\begin{abstract}
A commonly offered justification for patent trolls or nonpracticing entities ("NPEs") is that they serve as a middleman, facilitating innovation and bringing new technology from inventors to those who can implement it. We survey those involved in patent licensing to see how often patent license demands actually led to innovation or technology transfer. We find that very few patent license demands actually lead to new innovation; most demands simply involve payment for the freedom to keep doing what the licensee was already doing. Surprisingly, this is true not only of NPE licenses but even of licenses from product-producing companies and universities. Our results cast significant doubt on one common justification for patent trolls.
\end{abstract}

* Harry \& Lillian Hastings Professor, University of California Hastings College of the Law.

** William H. Neukom Professor, Stanford Law School; Partner, Durie Tangri LLP.

Thanks to Colleen Chien, Peter Detkin, Joe Fitzgerald, Rose Hagan, Bob Harris, Jay Kesan, Oskar Liivak, Brian Love, Doug Melamed, Lisa Larrimore Ouellette, Michael Risch, Dave Schwartz, and Ted Sichelman for comments on an earlier draft. We are grateful to Jenny Alsup, Afshin Emrani, Evan Frondorf, Cassidy Kim, Louis Lee, Alana Mannige, Robert Mazzola, and Daniel Yosef for their research assistance. (C) 2015 Robin Feldman \& Mark A. Lemley. 


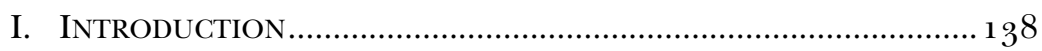

II. Patent Trolls and Patent Licensing ...................................... 139

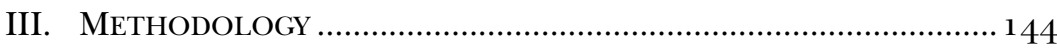

IV. RESULTS .......................................................................... 149

A. EXTENT AND DISTRIBUTION OF SUITS AND LICENSING

REQUESTS ................................................................... 149

B. DiD LICENSING LEAD TO INNOVATION OR TECHNOLOGY

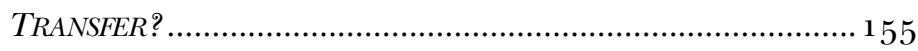

1. NPE Licenses Do Not Produce Technology

Transfer................................................................ $15^{6}$

2. University and Practicing Entity Licenses Rarely

Generate Technology Transfer..................................... 160

C. TECHNOLOGY TRANSFER AND LICENSING BY INDUSTRY ............... 166

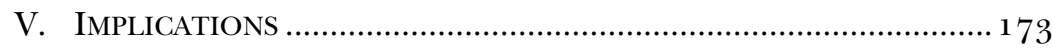

APPENDIX A ….............................................................. 178

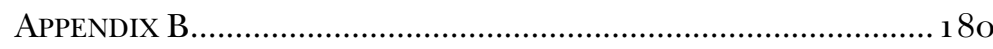

\section{INTRODUCTION}

Patent trolls-patent-holding entities that do not make any products but sue or threaten others with patent infringement-are the subject of intense debate. Congress is considering legislation to curb patent trolls, and many scholars have worried that the growing prevalence of patent lawsuits filed by trolls reflects a fundamental problem with the patent system. Defenders of patent trolls, meanwhile, have argued that they are desirable intermediaries that enable technology to move from the minds of inventors into the hands of those who can make productive use of it.

A critical factual assumption that underlies this debate is whether patent licensing by trolls is in fact a mechanism for technology transfer to the licensees and the creation of new products, or whether a request that a company take a patent license is simply a means of collecting money in exchange for agreeing not to sue. The answer matters not only for the debate over the desirability of patent trolls but for the health of the patent system altogether. Patents are supposed to promote not just invention but innovation-the development and deployment of new technology into the world. If they are serving this function, we should expect to see troll patent 
licenses leading to the deployment of new products or at least creating the proper environment for such deployment. If that is not happening, then aspects of the patent system begin to look more like economic waste, a tax on innovative companies being paid in part to inventors but increasingly to intermediaries that themselves contribute little to society.

In this Article, we offer a first window on that critical factual question by surveying people who actually engage in patent license negotiations to see whether the deals they strike lead to new products or to technology transfer or other markers of innovation. We find that very few patentee-initiated license requests result in any innovation, whether we measure that directly by looking for new products and features, or indirectly by looking for proxies such as the transfer of technology, sharing of personnel, or the development of joint ventures. Notably, our results seem to hold regardless of whether the patent owner seeking a license is a patent troll, a product-producing company, or a university. Based on our survey results, ex post patent licensing negotiations seem to be almost entirely divorced from innovation. Because of the small number of respondents, however, we encourage further research before drawing definitive policy conclusions.

To be clear, we do not find or suggest that there is no technology transfer occurring, or that the patent system cannot promote that technology transfer. Universities and inventors can and do strike deals with companies that are better positioned to implement the new ideas they develop, and these alliances have, indeed, led to valuable drugs and other products. But those deals frequently take place ex ante, before a patent issues and often before patents are even filed. It is the technology being sold; the patents accompany the sale of the technology. Ex post licensing demands and litigation-the focus of our Article-seem less promising.

In Part II, we discuss the debate over patent trolls and the relevance of technology transfer. In Part III, we explain our methodology. Part IV presents our results, and Part $\mathrm{V}$ offers some tentative policy implications of those results.

\section{Patent Trolls and Patent Licensing}

Patent trolls are the hottest topic of debate within patent law today. ${ }^{1}$ Trolls, also known as "non-practicing entities" ("NPEs") or "patent assertion entities" ("PAEs"), are individuals or businesses that do not make any products and instead make their money from licensing or asserting patents against entities that do make products. While there is some debate as to who fits in the troll category, under most reasonable definitions roughly half of the

1. See, e.g., Mark A. Lemley \& A. Douglas Melamed, Missing the Forest for the Trolls, 113 COLUM. L. ReV. $2117,2118-21$ (2013). 
patent suits filed in the last few years have been filed by trolls. ${ }^{2}$ In some industries, notably computers and telecommunications, the percentage is much higher. 3

Patent trolls are controversial. Many scholars, businesses, and policymakers argue that patent trolls represent a tax on innovation because they file costly lawsuits and obtain substantial settlements, but do not contribute anything of their own to society. 4 There have been substantial efforts to cut back on problematic lawsuits, both in the courts and in Congress. 5 Many of these efforts have been driven by concerns about the harm to innovation done by patent trolls.

At worst, patent trolls may be collecting payments on patents that are invalid, or not infringed. Given the economics of patent litigation, a rational company may choose to pay a license fee and thereby avoid the costs and risks of a lawsuit. ${ }^{6}$ The patent in that case is not benefitting society at all but rather serving as a drag on innovation.

2. See, e.g., Christopher A. Cotropia et al., Unpacking Patent Assertion Entities (PAEs), 99 MINN. L. REV. 649, 651-52 (2014); Robin Feldman et al., The AIA 5 oo Expanded: The Effects of Patent Monetization Entities, 17 UCLA J.L. \& TECH. 1, 37 (2013). See generally Colleen V. Chien, Patent Trolls by the Numbers (Santa Clara Univ. Legal Studies Research, Working Paper No. o8-1 3, 2013), http:// papers.ssrn.com/sol3/papers.cfm?abstract_id=2233041. The measurement is complicated not only by different definitions of patent trolls but by the fact that until September of 2011 a party could file suit against multiple defendants in a single case. Patent trolls tend to sue far more defendants than practicing entities, often suing dozens at the same time. So studies before 2011 of lawsuits filed-as opposed to the number of defendants sued-produced a misleadingly low measure of troll activity. Cotropia, Kesan, and Schwartz, using a restrictive definition of a patent troll, still find that roughly half of the assertions in both 2007 and 2012 were made by NPEs, though in 2007 many of those assertions were bundled into a single suit. Cotropia et al., supra, at 687, 692-96.

3. See, e.g., John R. Allison et al., Patent Quality and Settlement Among Repeat Patent Litigants, 99 GEO. L.J. 677, 691-92 (2011). Allison, Lemley, and Schwartz are currently embarked on a comprehensive study of how case outcomes differ between trolls and practicing entities. See generally John R. Allison, Mark A. Lemley \& David L. Schwartz, How Often Do Trolls Win Patent Suits? (2015) (unpublished manuscript) (on file with author).

4. See, e.g., JAMES BESSEN \& Michael J. Meurer, PATENT FaIlure: How Judges, Bureaucrats, AND LaWyers Put InNOVATORS AT Risk 144-47 (2008); Fed. Trade Comm'N, The Evolving IP MARKETPLACE: Aligning PATENT NOTICE AND REMEDIES With COMPETITION 53 (201 1), https://www. $\mathrm{ftc}$.gov/sites/default/files/documents/reports/evolving-ip-marketplace-aligning-patent-notice-andremedies-competition-report-federal-trade/ 1 10307patentreport.pdf; Tom Ewing \& Robin Feldman, The Giants Among Us, 2012 StAn. TeCH. L. Rev. 1, 25, 41; Charles Duhigg \& Steve Lohr, The Patent, Used as a Sword, N.Y. Times (Oct. 7, 2012), http://www.nytimes.com/2012/10/o8/technology/ patent-wars-among-tech-giants-can-stifle-competition.html; Ashby Jones, Patent 'Troll' Tactics Spread, WALl STREET J. (July 8, 2012 , 8:46 PM), http://online.wsj.com/article/SB1 ooo 14240527 02303292204577514782932390996.html; This American Life: When Patents Attack!, CHI. PUB. MEDIA (July 22, 2011), http://www.thisamericanlife.org/radio-archives/episode/441/whenpatents-attack.

5. See, e.g., Leahy-Smith America Invents Act, Pub. L. No. $112-29,125$ Stat. 284 (2011) (codified as amended in scattered sections of 35 U.S.C.); Saving High-Tech Innovators from

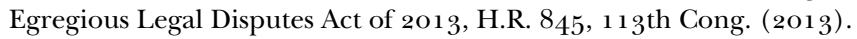

6. Lemley \& Melamed, supra note 1, at 2124 (noting the prevalence of this model). 
Defenders of patent trolls, by contrast, argue that they can serve as business intermediaries between inventors and commercializers. 7 The traditional theory of the patent system posits that patents encourage innovation by allowing inventors to exclude competitors from the market, thereby earning supracompetitive returns and recouping investment. ${ }^{8}$ A number of scholars have argued, however, that the patent system can encourage commercialization of inventions by allowing the inventor to control who can develop the technology.9 And if the inventor is not in a position to commercialize the invention at all, in theory, patents can serve as a mechanism that allows the inventor to provide her new idea to someone who can make use of it. On this theory, patent trolls can serve an intermediation function, helping to deliver good ideas to companies who can put them to good use. ${ }^{\circ}$ One can think of this as the efficient middleman

7. Ashish Arora \& Robert P. Merges, Specialized Supply Firms, Property Rights and Firm Boundaries, 13 INDUS. \& CORP. CHANGE 451, 470-72 (2004); Gerard N. Magliocca, Blackberries and Barnyards: Patent Trolls and the Perils of Innovation, 82 NOTRE DAME L. REV. 1809, 1818 (2007); James F. McDonough III, The Myth of the Patent Troll: An Alternative View of the Function of Patent Dealers in an Idea Economy, 56 EMORY L.J. 189, 190 (2006); Robert P. Merges, A Transactional View of Property Rights, 20 BERKELEY TeCH. L.J. 1477, 1519-20 (2005); Kristen Osenga, Formerly Manufacturing Entities: Piercing the "Patent Troll" Rhetoric, 47 CONN. L. REV. 435, 451 (2014); Jennifer Kahaulelio Gregory, Comment, The Troll Next Door, 6 J. MARshall ReV. InTELL. Prop. L. 292, 306-o9 (2007); Sannu K. Shrestha, Note, Trolls or Market-Makers? An Empirical Analysis of Nonpracticing Entities, 110 CoLUM. L. REV. 114 , 118 (2010). For discussion of this patent market idea, see, for example, Stéphanie Chuffart-Finsterwald, Patent Markets: An Opportunity for Technology Diffusion and FRAND Licensing?, 18 MARQ. INTELL. ProP. L. REV. 335 (2014); Andrei Hagiu \& David B. Yoffie, The New Patent Intermediaries: Platforms, Defensive Aggregators, and SuperAggregators, 27 J. ECON. PERSP. 45, 53-56 (2013); Ryan T. Holte, Trolls or Great Inventors: Case Studies of Patent Assertion Entities, 59 ST. LOUIS U. L.J. 1 (2014); Michael Risch, Licensing Acquired Patents, 21 GEO. MASON L. REV. 979 (2014).

8. See, e.g., William M. Landes \& Richard A. Posner, The Economic Structure of Intellectual Property LAW 319-26 (2003); Mark A. Lemley, The Economics of Improvement in Intellectual Property Law, 75 TEX. L. REV. 989, 993-96 (1997).

9. Michael Abramowicz, The Danger of Underdeveloped Patent Prospects, 92 CoRnell L. Rev. 1065, 1067-69 (2007); accord Michael Abramowicz \& John F. Duffy, Intellectual Property for Market Experimentation, $8_{3}$ N.Y.U. L. REV. 337, 398-404 (2008); F. Scott Kieff, Property Rights and Property Rules for Commercializing Inventions, 85 MINN. L. REV. 697, 707-12 (2001); Ted Sichelman, Commercializing Patents, 62 STAN. L. REV. 341, 345 (2010).

10. Daniel F. Spulber, Intellectual Property and the Theory of the Firm, in PERSPECTIVES ON Commercializing InNOvation 9, $3^{1}$ (F. Scott Kieff \& Troy A. Paredes eds., 2012) ("Specialized intermediaries began to create a market for patented technologies in the late 19th and early 20 th century .... This important development 'facilitated the emergence of a group of highly specialized and productive inventors by making it possible for them to transfer to others responsibility for developing and commercializing their inventions."); Daniel A. Crane, Intellectual Liability, 88 TEx. L. REV. 253, 286-87 (2009) ("Troll defenders counter that trolls are socially useful intermediaries between small inventors and commercialization. Small inventors may not have the resources to engage in detecting infringers, licensing negotiations, or patent infringement lawsuits against infringers. By buying up patents from small inventors, trolls may 'spur innovation by investing in undercapitalized projects and reducing transaction costs for small inventors who are routinely robbed by large corporations.'”); B. Zorina Khan, Trolls and Other Patent Inventions: Economic History and the Patent Controversy in the Twenty-First 
hypothesis. For this theory to work, however, patent trolls must actually facilitate the use of the patented inventions. Our study attempts to examine whether the activity of patent trolls does facilitate the development or use of new technology. As described below, the results are not encouraging.

If patent trolls do not operate as efficient middlemen, perhaps they are serving the social good as tax collectors for small inventors whose ideas have been appropriated. Under this theory, the patent holder has properly contributed to learning and dissemination by publishing its ideas in the form of a patent, and the product company has simply taken the idea from the patent's disclosure. The patent troll, therefore, would be operating as a tax collector to facilitate the transfer of an appropriate payment to the person who gave the idea to the world.

Several factors cast doubt on the appropriate payment theory, however. First, much of the patent troll activity occurs in fast-moving technologies such as computers and telecommunications where the patent is often on a technology that bears little resemblance to the defendant's product. In these circumstances, the patent troll asserts that the patent covers any means of solving a problem, even if the defendant's implementation looks nothing like the patentee's original idea. ${ }^{11}$ The distance between the patent disclosures in these cases and the accused product makes it unlikely that the company making the product learned the idea from the patent's disclosure. The hypothesis also assumes a level of quality in patents and adequacy of patent disclosure that is generally not attributed to the modern patent system by scholars and commentators. ${ }^{12}$ Finally, the evidence suggests that the overwhelming majority of patent cases do not involve alleged copying, but rather independent invention. ${ }^{13}$ If the parties taking patent licenses are doing so to avoid being sued on technology they themselves developed independently, the tax the patent system is imposing is a tax on one set of

Century, 21 GEO. MASON. L. REV. 825, 832 (2014) ("Specialized intermediaries are especially valuable in new or emerging markets and in instances in which asymmetries of information and other transaction costs are significant.").

11. See, e.g., Mark A. Lemley, Software Patents and the Return of Functional Claiming, 2013 WIS. L. REV. 905 .

12. See, e.g., U.S. GOV'T ACCOUNTABILITY OFFICE, GAO-1 $3-46_{5}$, INTELlECTUAL Property: Assessing Factors That AFFect PATENT Infringement Litigation Could Help IMPRove PATENT QUALiTY 45 (2013); Mark A. Lemley, Essay, Rational Ignorance at the Patent Office, 95 Nw. U. L. ReV. 1495, 15 OO-O1 (2001); $c f$. Robin FELdman, Rethinking PATENT LAW 52-53 (2012) (describing limitations of disclosure in the modern patent system); BRIAN T. YEH, CONG. ReSEARCH SERV., R42668, AN OVERVIEW OF THE "PATENT Trolls" Debate 9 (2013) (describing why "it is economically infeasible or irrational for [parties] to search through existing patents to avoid infringement").

13. There is no independent invention defense in patent law, and the vast majority of patent lawsuits are filed not against those accused of copying the invention from the patentee but against other inventors who came up with the same idea independently. See, e.g., Christopher A. Cotropia \& Mark A. Lemley, Copying in Patent Law, 87 N.C. L. REV. 1421, 1424 (2009) (finding that allegations of copying are quite rare in patent cases). 
inventors (those who actually put their inventions to good use) for the benefit of another set of inventors (those who did not). That is hard to justify. ${ }^{14}$

Under these circumstances, patent licensing does not benefit society by encouraging learning or dissemination of the patentee's invention. The dissemination of that technology was already happening, no thanks to the patentee; the patent troll is just collecting a tax from people who not only came up with the idea on their own, ${ }^{15}$ but actually put the invention into practice.

One could argue that in its tax collector role, patent trolls are at least returning dollars to original inventors, thereby encouraging innovation by facilitating the rewards that the patent system promises to those who invent and disclose. ${ }^{16}$ In the absence of technology transfer, however, it is reasonable to question how much society wants to invest in moving money from one independent inventor to another. Further, studies suggest that such rewards are not flowing. In what economists are calling the "leaky bucket," only an estimated $20 \%$ of the payments to NPEs get back to the original inventor or into internal research and development by the NPE. ${ }^{17}$ And there is some evidence that the prospect of later patent licenses is not what motivates many inventors, particularly in universities. ${ }^{18}$

If patent trolls are not returning much to original inventors, it will be particularly important to see if their activity is leading to new innovation. Otherwise, all of this patent assertion and licensing activity may simply be a

14. If independent invention is widespread, it may suggest that the bar for obviousness is set too low within the patent system. In other words, if others can develop an idea without the benefit of the inventor's wisdom, perhaps we are not seeing wisdom but rather an advance that is obvious to those in the art. Cf. Tun-Jen Chiang, A Cost-Benefit Approach to Patent Obviousness, 82 ST. John's L. REV. 39, 94-96 (2008); Mark A. Lemley, Should Patent Infringement Require Proof of Copying?, 105 MICH. L. REV. 1525, 1534-35 (2007) (arguing that evidence of independent invention should be a factor pointing toward obviousness). Courts in a prior era had given more credence to this evidence. See, e.g., Concrete Appliances Co. v. Gomery, 269 U.S. $177,185(1925)$ (stating that independent inventions "within a comparatively short space of time ... are in themselves persuasive evidence that this use ... was the product only of ordinary mechanical or engineering skill").

15. Some independent invention occurs after the patentee invents, but before the patent has issued. Other independent invention occurs even before the patentee invents, but it may not bar the later inventor from patenting if the first inventor kept the idea secret. See, e.g., ROBERT PATRICK MERGES \& JOHN FITZGERALD DUfFy, PATENT LAW AND POLICY: CASES AND MATERIALS 509-1 1 (4th ed. 2007).

16. Trolls may be intermediaries in this very different sense-not transmitting new technology to licensees and defendants, but facilitating suit by individuals or small companies who could not otherwise afford to sue. See, e.g., Stephen H. Haber \& Seth H. Werfel, Why Do Inventors Sell to Patent Trolls? Experimental Evidence for the Asymmetry Hypothesis (Apr. 27, 2015) (unpublished manuscript), http://papers.ssrn.com/sol3/papers.cfm?abstract_id=2552734 (finding evidence in controlled experiments to support this hypothesis).

17. See James Bessen \& Michael J. Meurer, The Direct Costs from NPE Disputes, 99 CORNELL L. REV. 387, 411 (2014); Fiona M. Scott Morton \& Carl Shapiro, Strategic Patent Acquisitions, 79 ANTITRUST L.J. 463, 482-83 (2014).

18. See, e.g., Brian J. Love, Do University Patents Pay Off? Evidence from a Survey of University Inventors in Computer Science and Electrical Engineering, 16 YALE J.L. \& TECH. 285 (2014). 
tax on current productivity with relatively little return to the innovation ecosystem.

Thus, in evaluating the social welfare contribution of patent trolls, we would like to know whether their patent licensing actually results in new products, learning, or technology transfer by licensing targets. The value of that information is not limited to contributing to the patent troll debate. Practicing entities also license their patents to others. Mark Lemley and Doug Melamed have suggested that trolls are not themselves the problem, but rather a symptom of larger problems with the patent system. ${ }^{19}$ It makes sense to ask not merely whether patent trolls are actually facilitating innovation through after-the-fact patent licensing, but whether practicing entities are as well.

Our goal in this Article is to begin to shed light on this critical question. To do that, we decided to ask the people who know-the ones who enter into such licensing agreements.

\section{Methodology}

In this Part, we describe the methodology of our survey, along with the limitations of survey methodology in general and of this study in particular.

We developed a tree of questions to be presented to survey respondents. After developing a draft question tree, we tested the questions using two attorneys at separate large law firms and two academic colleagues. Each academic tester held both a J.D. degree and a Ph.D., and also had extensive experience in sociology and in empirical studies. The attorney testers had active practices advising product companies who receive patent licensing and litigation demands. Given the potential to discuss study intent and approaches with the testers, we chose as testers attorneys at law firms, rather than attorneys at product companies, to avoid the possibility of tainting any study participants.

These testers provided suggestions for improving question clarity and ensuring neutrality of the wording, and we revised the survey questions accordingly. After finalizing the questions and study approach, the study was given clearance by a regulatory opinion of the Western Institutional Review Board, which determined that the study fit the exemption criteria for human subjects research under 45 C.F.R. $\S 46.101$ (b) (2). ${ }^{20}$

The survey was distributed to attorneys who work in-house at product companies. We chose in-house attorneys at product companies because they are best positioned to know whether their company actually implemented new technology as a result of a licensing deal or negotiation. Contacting

19. Lemley \& Melamed, supra note 1, at 2121 . For discussions of patent privateering and the blurring of the line between trolls and practicing entities, see, for example, Ewing \& Feldman, supra note 4, at 6o-70; John M. Golden, Patent Privateers: Private Enforcement's Historical Survivors, 26 HARV. J.L. \& TECH. 545, 557-72 (2013).

20. A full copy of the survey instrument is attached as Appendix B. 
licensing lawyers who send demands but who do not work at product companies runs the risk that the lawyer will hope or assume that the licensing target adopted a new technology without having any first-hand knowledge on the matter.

There is some risk that the recipients of licensing demands may be motivated to understate the effect of those demands, skewing our results. We think this is unlikely, however. First, the motivation to bias the results of an academic survey seems weak. Second, licensing lawyers in product-producing companies tend to negotiate both as patent owners and as potential licensees in different cases, so they are less likely to suffer from systematic bias than lawyers who only negotiate for one side. ${ }^{21}$ Nonetheless, future researchers might want to survey the lawyers making licensing demands. At the least, any discrepancy between their accounts and the accounts of licensees would suggest some bias in one cohort or the other that would need to be taken into account. As we note above, however, we think it is the licensee-user, not the licensor, who is likely to have better information on the use the licensee made of the technology.

We separated product companies into 11 different industry sectors. These sectors were identified based on the work of Mark Lemley and his coauthors John Allison and David Schwartz, who broke patent lawsuits into different functional industry categories. ${ }^{22}$ The 11 industry sectors are: Computers \& Other Electronics; Semiconductor; Pharmaceutical; Medical Devices, Methods \& Other Medical; Biotechnology; Communications; Transportation; Construction; Energy; Goods \& Services for Industrial \& Business Uses (i.e., goods and services for wholesale uses that are not in another category, including business method inventions); and Goods \& Services for Consumer Uses (i.e. goods and services for retail uses that are not in another category, including business method inventions). We asked participants to identify their companies according to those 11 industry sectors.

The surveys were administered through Qualtrics, a survey firm. All information was anonymized and aggregated for publication here. In addition, all responses were anonymized so that even the authors could not see any identifying information about respondents. Respondents were asked whether they would be willing to participate in future research and, if so, to provide contact information. That contact information was provided to the authors separate from any individual survey responses.

The surveys themselves were distributed in a variety of ways. First, we emailed surveys to in-house attorneys-identified using a database from

21. Future research might explore this potential bias by trying to pair the descriptions given by licensors and licensees. Doing so would necessarily sacrifice anonymity, however, and so is unlikely to be feasible.

22. See John R. Allison et al., Understanding the Realities of Modern Patent Litigation, 92 TEX. L. REV. 1769, $1178-79$ (2014) (developing these categories and explaining them in detail). 
Hoover's D\&B (commonly referred to as Dun \& Bradstreet). The database was mined in order to identify survey participants who could represent 11 different industry sectors (Appendix A, Column 1) in the United States. The 11 different industry sectors were created by mapping the appropriate "Hoover's Industries" categories onto the industry sectors (Appendix A, Column 2).

The participants were chosen based on whether their job title was related to the relevant legal profession. The following Hoover's "Job Function" categories were utilized to select participants in 10 out of the 11 categories: Vice-President Legal, Contract Law, Contract Manager, Corporate \& Business Law, Corporate Counsel/Legal, Group \& Corporate Practice, Legal Executive, Counsel, Attorney, Commercial Law, General Counsel, General Legal Practice, and Patent Law. For the 11 th industry sector (Goods \& Services for Industrial \& Business Uses), the number of legal professionals was very large and therefore the list of participants was chosen from only the following categories, which are a subset of the previously mentioned set: VicePresident Legal, Contract Manager, Corporate \& Business Law, Corporate Counsel/Legal, Legal Executive, Attorney. Where time and information permitted, phone calls were made to the company to identify the proper recipient and to request participation in the survey. The search results were filtered further-using Hoover's People Search Results based on job function and its position on Hoover's Job Function list, beginning with the function in the highest position and progressing to the lowest-to ensure that no more than a handful of people at any single firm would receive the survey. There is a risk that more than one person at a single firm could have responded to the survey, which would over-represent a single company's experience. We have described this risk and the way it was addressed in the limitations discussion below.

The Hoover's D\&B database represents the most comprehensive commercially available collection of companies. Nonetheless, it, like every database, has limitations. It may overrepresent large and medium-sized companies at the expense of startups. The fact that we surveyed legal and contract managers may further skew our study towards companies large enough to have at least one lawyer or contract manager, which will exclude very small startups. Our study is therefore best understood as a study of established companies rather than startups. ${ }^{23}$

23. Other work has surveyed startups for their experience with patents. See, e.g., Stuart J.H. Graham et al., High Technology Entrepreneurs and the Patent System: Results of the 2008 Berkeley Patent Survey, 24 Berkeley TECH. L.J. 1255 (2009); Colleen V. Chien, Startups and Patent Trolls (Santa Clara Univ. Sch. of Law, Working Paper No. o9-1 2, 2012 ), http:/ / papers.ssrn.com/sol3/papers. cfm?abstract_id=2 146251; cf. Robin Feldman, Patent Demands E Startup Companies: The View from the Venture Capital Community, 16 YALE J.L. \& TECH. 236, 279-80 (2014) (surveying venture capitalists to learn how patents affect startups). 
In addition to the Hoover's $\mathrm{D} \& \mathrm{~B}$ recipients, links to the survey were posted for in-house counsel groups. These were posted using LinkedIn or other affinity groupings for a total of 12 groups. We used a different survey link for each group, including for the Hoover's D\&B group. This allowed us to compare the results of each group so that if any questionable activity by respondents or any anomalies in the data occurred, we would have the opportunity to identify it. For example, given the intense interest in this area and the open nature of the surveys, it would be possible, in theory, for a respondent to try to affect the data by submitting multiple responses or by enlisting others to do so. Isolating the responses from the different group postings allowed us to monitor for data that might widely and inexplicably vary from responses received from other groups. If such a variation had occurred, we could have looked further to try to determine if characteristics of the variant group might have led to different responses or if we should be concerned about possible data manipulation. No major discrepancies emerged. ${ }^{24}$

Roughly two-thirds of the total responses received came from either the Hoover's D\&B participants or from the group titled "In the House." Approximately 10 to 20 responses each came from the following groups: American Bar Association Corporate Counsel Committee, High-Tech Law Group, InHouse Legal, In-House Counsel, and Internet Association. The following groups generated fewer than ten responses each: Mobile Marketing Association, Telecomm Counsel, Generals of the Revolution, Silicon Valley Leadership Group, e-Legal In-House, Computer and Communications Industry Association, and CPF. Groups that did not generate any responses are not listed here or included in the study results in any way. As described above, participants were asked to classify their company within 1 of 11 industry groups. This allowed us to compare responses across industry groups.

Researching any topic through voluntary survey responses carries significant limitations. Responses can by skewed by who chose to respond, creating limitations for reaching conclusions that are accurate for the entire population. For the topic of patent assertion, those who choose to respond may be those who have had particular types of experiences with patent assertion or who hold views sufficiently strong for them to be willing to spend time answering questions. The resulting nonresponse bias can move the results of the sample away from the characteristics of all companies nationwide. That said, we take some comfort in the fact that many of our respondents had not in fact encountered licensing efforts or lawsuits, ${ }^{25}$

24. One group with fewer than ten responses had a significant overrepresentation in the

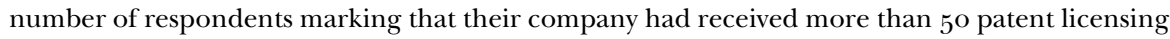
or settlement requests per year. However, these responses represent a very small subset of the data not affecting the overall results, and the rest of these respondents' answers are not noticeably out of line with the data.

25. See infra Part IV. 
suggesting that the respondents were not limited to those with a particular set of experiences. But we cannot be sure that the respondents are a representative sample of all companies.

Responses to the type of survey questions in this study are also not independently verifiable by the researchers. Survey responses are based on the respondent's recollections, which may be limited by memory effects, subjective perceptions, and conscious or subconscious biases. In an area that is the subject of considerable public debate at the moment, these perceptions can have an impact on respondent's responses.

Posting on groups also created the risk that individuals could fill out more than one survey. We did eliminate some duplicate responses from the results, where in all cases it appeared that the respondent had failed to finish the survey in one submission and then completed it in the other entry. Of course, it is possible that an individual still could have completed more than one survey inadvertently, perhaps by using different devices or accounts. Given how difficult it is for any individual to take the time to complete survey questions, however, we find it unlikely that this could have occurred. A more likely risk, however, concerned the possibility that more than one individual at a particular company could have completed a survey, which could overrepresent that company's experience in the results. There is some reassurance from the respondents who volunteered to provide additional information in the future. A large number of respondents answered that they would be willing to participate in additional research and provided contact information. Looking at that list, there were only two companies that had more than one respondent. This makes it less likely that the problem was widespread, but such possibilities could not be eliminated. Finally, it is certainly possible that respondents could have chosen inaccurate answers or engaged in repeat surveys to intentionally distort the study. Although that risk cannot be eliminated from any voluntary survey, we were able to mitigate this risk by creating a different survey link for each group. This made it more likely that we would be able to identify odd results. It also made it less likely that any data manipulation could extend across the full sample set.

Most important, it is critical to highlight the limitations of the low response rate and small sample size. The response rate is complicated by the fact that we provided links to certain associations of in-house counsel to allow their members to respond. Because we did not distribute those latter surveys directly to prequalified individuals, we cannot assess how many people considered responding to the survey but ultimately did not do so. A small response rate increases the risk of selectivity bias among those who do respond.

In addition, many of the questions have a response rate lower than the entire sample of 181 respondents. For example, only a subset of respondents (97) worked at companies that had received patent demands. Of those, not all respondents had received patent demands from each category of patent 
holders (NPEs, universities, competitors, etc.). Thus, questions about patent assertions from each of those subgroups will have a lower response rate than the subset of 97 . And those responders represent a variety of industries. Thus, the sample is small enough that statistical significance should not be inferred from any of the results.

Despite these limitations in sample size, the results offer some quantitative progress towards understanding whether innovation results in response to modern patent assertion. We believe this anecdotal and observational information provides a useful insight into an area that has been shrouded in secrecy. In particular, the paucity of available information on this topic and the difficulty of collecting such information make our survey a useful starting point, and one that we hope other academics and government actors will continue to pursue and expand.

\section{RESUlts}

\section{A. EXTENT AND DISTRIBUTION OF SUITS AND LICENSING REQUESTS}

In this Part, we summarize the results of our survey. We first asked respondents whether in the last five years, their company had received any licensing or settlement requests from a patent holder. These were defined in the question to include either calls or letters doing any of the following: suggesting areas of mutual interest or joint ventures, offering to license patents, threatening litigation, giving notice of intent to file an infringement lawsuit, or noticing the filing of an actual infringement lawsuit. Fifty-four percent of the respondents had received such calls or letters.

Figure 1. Respondents Receiving Patent Licensing or Settlement Requests

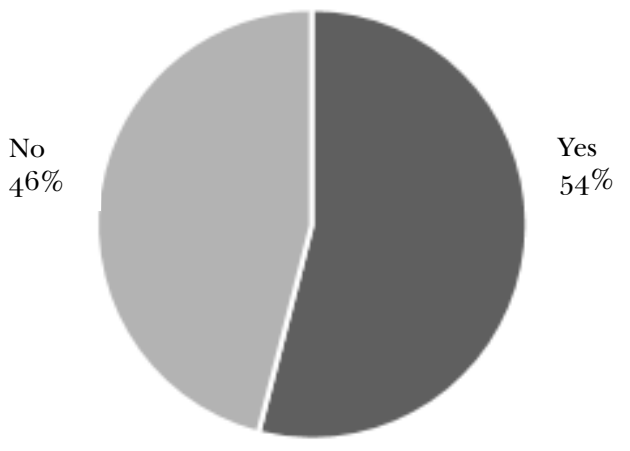

Notably, because the focus of our study was on the efficient middleman hypothesis as applied to patent trolls, our study focused on licensing requests or threats initiated by the patent owner. We did not study circumstances in which companies reached out to patent owners to seek a license to particular technology or to partner in developing an idea. New innovation and 
technology transfer may be more likely in those latter circumstances.

Those who had received licensing or settlement requests in the past five years were spread across all industry sectors. The largest groupings, however, were in the categories of Goods \& Services for Consumer Uses and Computer \& Other Electronics, which accounted for $21 \%$ and $20 \%$ of responses, respectively. Other larger groupings included Industrial Goods \& Services (15\%) and Communications (14\%). Three other categories included 6-7\% of the respondents each: Semiconductors (7\%); Pharmaceuticals $(7 \%)$; and Medical Devices, Methods \& Other Medical (6\%). The remaining sectorsBiotechnology, Transportation, Construction, and Energy-each had smaller percentages of the respondents who had received patent licensing or settlement requests.

Figure 2. Respondents Classified by Industry

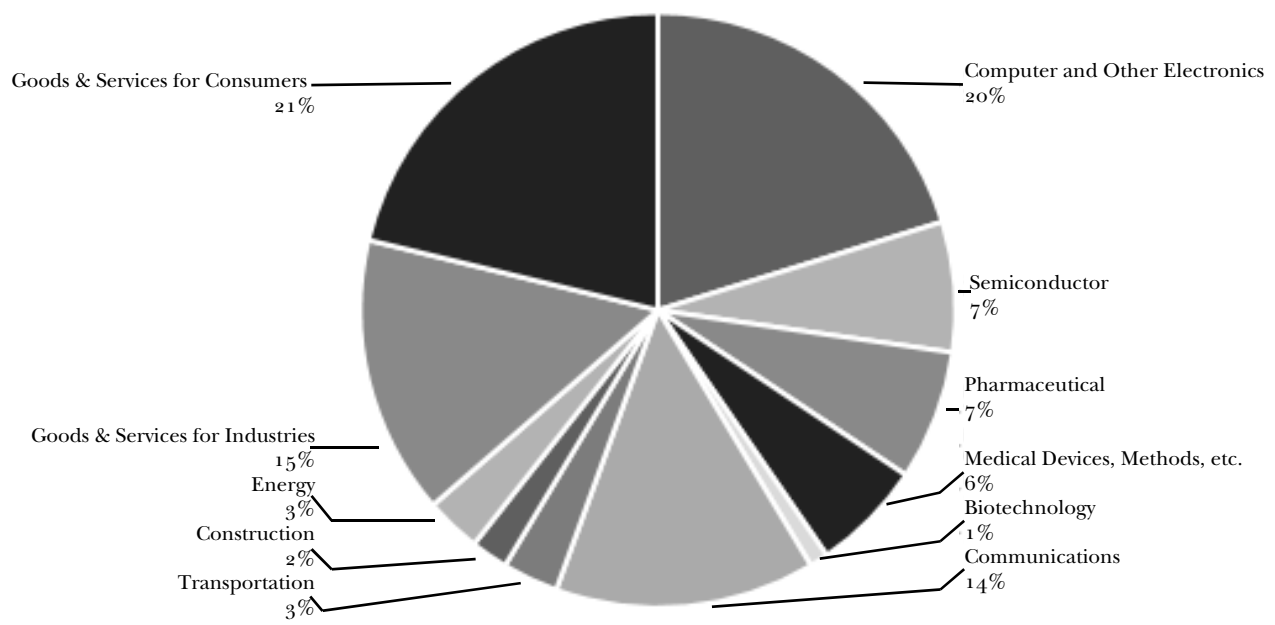

Most of the respondents that had received requests were large companies. Seventy percent had annual revenue of over $\$ 1$ oo million. The remainder of the respondents who had received requests were evenly spread at six to nine percent across other annual revenue categories. 
Figure 3. Respondents' Annual Revenue

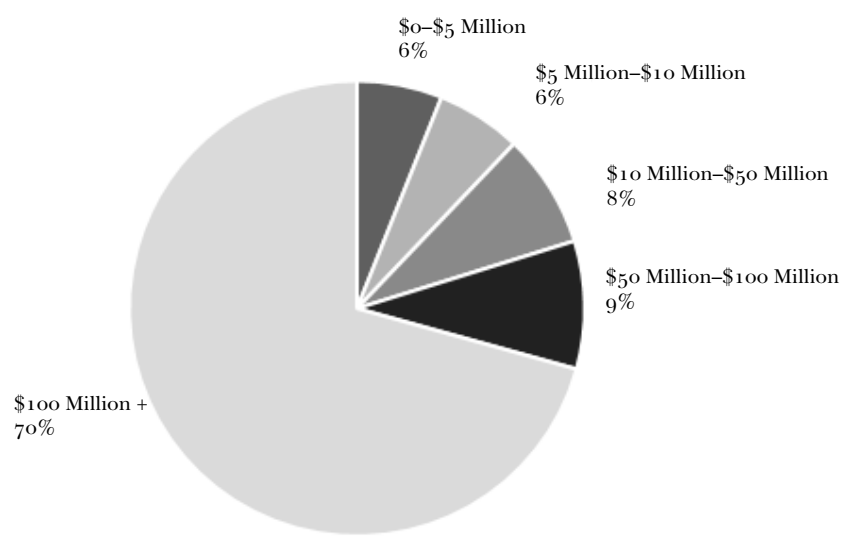

The location of company headquarters for respondents was not surprising. Respondents who had received licensing or settlement requests were largely headquartered in the major innovation sectors of the country. Thirty-one percent were in Northern California, and another $4 \%$ in Southern California. Groupings from $5-8 \%$ were in other states that have significant innovation sectors including New Jersey (8\%), New York (8\%), Texas $(8 \%)$, Illinois $(6 \%)$, and Georgia $(5 \%)$. Smaller groupings came from Delaware $(4 \%)$, Virginia (4\%), Pennsylvania (3\%), Wisconsin (3\%), Connecticut $(2 \%)$, Maryland (2\%), Minnesota (2\%), Washington ( $2 \%)$, Colorado ( $1 \%)$, Kansas $(1 \%)$, Louisiana (1\%), Massachusetts (1\%), Michigan (1\%), and New Hampshire $(1 \%) .{ }^{26}$

Of those who had received requests, roughly half had received requests from one to five times a year. Roughly one-quarter had received such requests less than once a year. Interestingly, a segment of the respondents seemed to draw a strikingly high number of licensing and settlement requests. Twelve percent received requests 11 to $5^{\mathrm{O}}$ times a year, and another four percent received more than $5^{0}$ requests a year. This is consistent with prior suggestions that patent assertions are not evenly distributed across all companies and industries, but are concentrated in certain sectors of the economy. ${ }^{27}$ It also gives us further comfort that our results are not driven by a few companies with a particular interest in patent license demands.

26. For an argument that innovation in many industries is geographically concentrated, and that patent law can use that fact to develop judicial centers of expertise, see generally Jeanne C. Fromer, Patentography, $8_{5}$ N.Y.U. L. REV. 1444 (2010).

27. See, e.g., DAN L. Burk \& MARK A. Lemley, The PATENT Crisis And How the Courts Can SOLVE IT 49-65 (2009) (discussing the industry-specific nature of patent enforcement). 
Figure 4. How Often Were Respondents Approached with Patent Licensing and Settlement Requests?

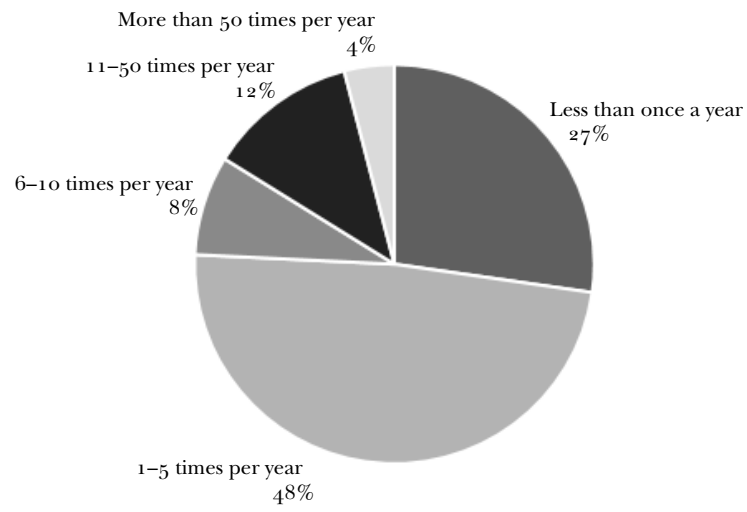

Respondents were asked to identify the type of party initiating the licensing or settlement requests and the percentage of requests that came from each type of entities. Respondents were given the choice of selecting: (1) competitors; (2) product-producing companies that are not competitors; (3) entities or individuals whose core activity involves licensing or litigating patents, or NPEs; ${ }^{28}$ (4) universities; or (5) nature of party is unclear. ${ }^{29}$ For about $60 \%$ of the respondents, the majority of requests came from entities or

28. Colleen Chien has dubbed these entities "patent assertion entities," distinguishing them from other forms of NPEs such as individual inventors and universities. Colleen V. Chien, From Arms Race to Marketplace: The Complex Patent Ecosystem and Its Implications for the Patent System, 62 HASTINGS L.J. 297, 300 (2010). We use the broader term NPE because asserters in this survey category include individual inventors and companies who developed the idea but never turned it into a product. Nonetheless, it is worth bearing in mind that our NPE category excludes universities even though they are not strictly product-producing companies. See generally Mark A. Lemley, Are Universities Patent Trolls?, 18 Fordham InTell. Prop. Media \& ENT. L.J. 611 (2008).

29. As an aside, the design of this question allows us to distinguish between productproducing companies that are acting to protect their competitive interests and productproducing companies that are acting more like NPEs interested in generating revenue from outside the line of business. Cf. Lemley \& Melamed, supra note 1, at 2146-66 (noting that practicing entities can often behave in ways similar to trolls). Prior studies of patent trolls have been unable to distinguish the two without investigating the technology of each lawsuit in detail. See, e.g., John R. Allison et al., Extreme Value or Trolls on Top? The Characteristics of the Most-Litigated Patents, $15^{8}$ U. PA. L. REV. 1, 16-19, 31-32 (2009); Cotropia et al., supra note 2, at 654, 679-82. The line between competitive and noncompetitive companies is not always clear, however. It is possible, for example, that a competitor's suppliers might choose to assert patents in an effort to improve the competitive posture of its own chain of production. If that were the case, part of the activity in the category of product-producing companies that are not competitors could represent an attempt to protect competitive interests. 
individuals whose core activity involves licensing or litigating patents. $3^{\circ}$ More than two-thirds of that $60 \%$ received all or almost all of their licensing requests from NPEs. $3^{1}$

The survey then asked respondents to provide information on those requests for patent licenses or settlements. The questions separated the information into the five types of parties who might have initiated responses: (1) competitors; (2) product-producing companies that are not competitors; (3) entities or individuals whose core activity involves licensing or litigating patents; (4) universities; or (5) nature of party is unclear. In other words, we asked for the same information about the respondent's experiences with each of the five categories of parties who could have initiated requests. The survey covered both information about the ultimate resolution of the request and information about whether a lawsuit was filed.

On the litigation information, we asked respondents to consider those cases in which a request led to a patent license. For those cases, we asked how often a lawsuit was filed prior to reaching the license agreement. Again, the questions were asked separately for each type of party that might have initiated the request.

The majority of requests did not lead to settlement agreements, no matter what type of party initiated the request. Specifically, the majority of respondents answered that requests led to a patent license from zero to ten percent of the time regardless of whether litigation was initiated. That result suggests that actually taking a license is rare. That in turn means that in many instances a licensing request is either ignored or refused after negotiation. $3^{2}$ Thus, one respondent explained that "[w] e did not take any offered licenses."

Both competitors and those whose core activity is licensing and litigating patents fared somewhat better than others in seeking licenses. In the case of requests from competitors and NPEs, roughly half of the respondents reported that requests led to licenses in the "rare" category of zero to ten percent of the time. When universities and product-producing companies that were not competitors initiated the requests, almost three-quarters of respondents in each category reported that requests rarely led to licenses. 33

30. Not all respondents who answered the question also included a percentage. The figure above reflects the 60 respondents who specified a percentage. To be conservative, we did not count those who responded with $5^{\mathrm{o}} \%$ as indicating that a majority of requests came from those whose core activity involves licensing or litigating patents.

31. Specifically, $72 \%$ of the $60 \%$ who received a majority of requests from entities or individuals whose core activity involves licensing or litigating patents-or $43 \%$ of the whole group of those who had received requests from any kind of entity-had received at least $90 \%$ of the licensing requests from entities or individuals whose core activity involved licensing or litigating patents.

32. This is consistent with Lemley's suggestion that in many instances companies simply ignore patents. Mark A. Lemley, Ignoring Patents, 2008 MICH. ST. L. REV. 19, 22 (reporting the received wisdom among licensing lawyers that one should always "ignore the first cease-and-desist letter one receives").

33. In other words, three-quarters of the respondents answered zero to ten percent. 
For those requests that led to licenses, we also asked how often a lawsuit was filed prior to reaching a settlement agreement. The responses suggest that most licensing from requests such as these occurs outside the courthouse. 34 Specifically, our survey showed that in the experience of most respondents, when requests led to patent licensing, lawsuits were rarely filed first. For example, $61 \%$ of respondents suggested that when requests from competitors led to patent licenses, a lawsuit was filed first zero to ten percent of the time. For requests from product-producing companies that are not competitors, $75 \%$ of respondents said that a lawsuit was filed first zero to ten percent of the time; and for requests from universities, $82 \%$ of respondents said that a lawsuit was filed first zero to ten percent of the time.

Interestingly, the experience of most respondents with NPEs was somewhat different. In the experience of most respondents, when requests that came from NPEs led to patent licenses, lawsuits preceded a license more frequently. In particular, only $48 \%$ of respondents noted that lawsuits were filed rarely when requests led to licensing-as compared to $61 \%$ with competitors. 35

Put another way, only $27 \%$ of respondents said that competitors filed lawsuits in a majority of the cases in which requests led to licensing. In contrast, $40 \%$ of respondents said that NPEs filed lawsuits in a majority of cases prior to a settlement.

From either perspective, it appears that NPEs more often filed lawsuits prior to settlements. This could suggest that NPEs more often feel the need to file lawsuits in order to get companies to take a license because the companies are less willing to deal with them. It could also suggest, however, that NPEs are more aggressive in their licensing behavior, choosing to file first and talk later. $3^{6}$ This notion, that NPEs are more aggressive and resort to the courthouse more frequently, echoes other anecdotal discussions of NPE behavior as well as studies suggesting that the percentage of patent litigation

34. This type of response dovetails with other studies suggesting that on the whole most requests for patent licenses never progress to the stage of a lawsuit. See Feldman et al., supra note 2, at 32. The study notes that the 2013 White House Report on Patent Assertion cites conservative estimates of "the number of patent threats in 2012 at 6o,ooo with the actual number more likely over 100,ooo." Id. Comparing even the more conservative number of patent demands with the

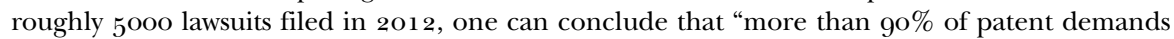
never reach the courthouse door." Id.; $c f$. Lemley, supra note 12, at $15^{\circ} 7$ (estimating without data that there are five times as many patents licensed for a royalty as there are infringement suits filed).

35. The rough comparison holds up across all categories of responses. For competitors, the responses were: $\mathrm{O}-10 \%$ filed first $(61 \%) ; 10-25 \%$ filed first $(11 \%) ; 25^{-} 5 \mathrm{O} \%$ filed first $(3 \%) ; 5^{\mathrm{O}}-75 \%$ filed first $(3 \%) ; 75^{-100 \%}$ filed first $(24 \%)$. For entities and individuals whose core activity involves licensing or litigating patents, the responses were: $0-10 \%$ filed first $(48 \%) ; 10-25 \%$ filed first $(9 \%) ; 25^{-5} 5^{\circ} \%$ filed first $(3 \%) ; 5^{\mathrm{O}-75} \%$ filed first $(9 \%) ; 75^{-100} \%$ filed first $(31 \%)$.

36. See, e.g., Brian J. Love, An Empirical Study of Patent Litigation Timing: Could a Patent Term Reduction Decimate Trolls Without Harming Innovators?, 161 U. PA. L. REV. 13o9, 1354 (2013); cf. Ronald A. Bleeker \& Michael V. O'Shaughnessy, One Year After MedImmune-The Impact on Patent Licensing $\mathcal{E}^{2}$ Negotiation, 17 FED. CIR. B.J. 401, 431-32 (2008) (suggesting this strategy). 
filed by NPEs has risen in recent years. In short, regardless of the reasons for it, respondents suggest that NPEs resort to the courthouse more frequently.

\section{B. DiD LICENSING LEAD TO INNOVATION OR TECHNOLOGY TRANSFER?}

Startups and established companies often seek knowledge, information, or know-how from others, and that often accompanies a patent license. 37 Economic literature suggests that technology transfer is often more complicated than the simple license of a patent. It includes the transfer of know-how, "complementary assets," ${ }^{8}$ and other "peripheral disclosures." 39

The focus of our study and the most important part of the results concerned whether the licensing that resulted from such requests led to any innovation or technology transfer, rather than licensees simply paying for the freedom to operate as they were already doing. As described above, to explore this question, we looked for indicators that might suggest innovation is occurring through this licensing activity. We call these factors "markers of innovation." The markers of innovation include direct indicators of innovation, such as whether the companies added new products or features with the technology they licensed. We also included indirect markers of innovation, including whether the patent holder transferred any know-how or anything else along with the patent license. $4^{\circ}$ Thus, we asked whether the patent holder transferred technical knowledge, and we also asked whether the patent holder transferred personnel (for example through a consulting agreement). Finally, particularly mindful of the ways in which innovation

37. See Graham et al., supra note 23 , at 1317 .

38. See David J. Teece, Profiting from Technological Innovation: Implications for Integration, Collaboration, Licensing and Public Policy, ${ }_{5} 5$ RES. POL'Y 285, 293 (1986).

39. See generally Jason Rantanen, Peripheral Disclosure, 74 U. PITT. L. REV. 1 (2012).

4o. It is well established in the economic literature that effective technology transfer requires informal know-how and secrets as well as the technology publicly described in the patent. See, e.g., ASHISH ARORA ET AL., MARKETS FOR TECHNOlOgY: THE ECONOMICS OF INNOVATION AND CORPORATE STRATEGY (2OO1) (estimating that the markets for technology are much larger than the market for patent licensing); Teece, supra note 38 , at 288-9o (explaining that returns to IP often depend on informal know-how and "complementary assets"). That is particularly true in light of evidence that patents do not actually serve to disclose much knowledge to scientists, in part because of the delay in issuing them and in part because of deliberately opaque patent drafting. See, e.g., Alan Devlin, The Misunderstood Function of Disclosure in Patent Law, 23 HARV. J.L. \& TECH. 401, 403 (2010); Mark A. Lemley, The Myth of the Sole Inventor, 110 MICH. L. REV. 7o9, 745 (2012) ("Simply put, inventors don't learn their science from patents."); Doug Lichtman, Substitutes for the Doctrine of Equivalents: A Response to Meurer and Nard, 93 GEO. L.J. 2013, 2023 (2005) ("[V]ery few people read patents outside of the litigation and licensing contexts."); John M. Olin, Note, The Disclosure Function of the Patent System (or Lack Thereof), 118 HARV. L. REV. 2007, 2019-20 (2005) ("[M] any innovators have ceased using patents as a research tool ...."). Even supporters of disclosure theory like Fromer acknowledge that "a good deal of evidence suggests that technologists do not find that [patents] contain [] pertinent information for their research." Jeanne C. Fromer, Patent Disclosure, 94 IOWA L. REv. 539, 560 (2009). But cf. Lisa Larrimore Ouellette, Do Patents Disclose Useful Information?, 25 HARV.J.L. \& TECH. 545, 6o3 (2012) (surveying scientists and finding that some, albeit a minority, do learn from patents). 
progresses from university licensing, as well as across product companies at times, we also asked whether a joint venture was created along with the patent license.

We wish to emphasize once again that our survey studied companies who received unsolicited licensing requests from third parties. We did not surveyand do not report-on the practice of entering into technology transfer agreements before embarking on development of a new technology. Those agreements undoubtedly exist, particularly with universities but also among product companies, and they often involve the transfer of patent or trade secret rights along with the technology.

\section{NPE Licenses Do Not Produce Technology Transfer}

The responses suggest that licensing requests from NPEs rarely lead to any markers of innovation. With particular unanimity, respondents reported that licenses taken from NPEs rarely led to any new products or features. Specifically, $92 \%$ of respondents reported that they added new products or features from the technology they licensed from NPEs zero to ten percent of the time and only two percent of respondents indicated they developed new products more than $25 \%$ of the time. In other words, although much of the activity related to requests for licensing or settlement requests originated from NPEs, the resulting licenses lead to few, if any, product advancements. And it is quite possible that those few companies who did develop a new product as a result of NPE patent assertions did not make an improved product, but simply chose to design around the patent to minimize the obligation to pay for a license to products in the future. $4^{1}$ In other words, those few instances

41. See, e.g., Mark A. Lemley \& Carl Shapiro, Patent Holdup and Royalty Stacking, 85 TEX. L. REV. 1991, 1995-2004 (2007) (modeling the optimal response to patent litigation, which often involves designing around the patented invention); see also FELDMAN, supra note 12, at 40-74, 212 (describing patents as an opportunity to bargain and including a chapter on how modern patents operate). Design-arounds can be valuable. Indeed, designing around a patent is an expected and even desirable part of the patent system. Warner-Jenkinson Co. v. Hilton Davis Chem. Co., 520 U.S. $17,3^{6}$ (1997) (contrasting "the intentional copyist making minor changes to lower the risk of legal action" with "the incremental innovator designing around the claims, yet seeking to capture as much as is permissible of the patented advance"); see also Slimfold Mfg. Co. v. Kinkead Indus., Inc., 932 F.2d 1453, 1457 (Fed. Cir. 1991) ("Designing around patents is, in fact, one of the ways in which the patent system works to the advantage of the public in promoting progress in the useful arts, its constitutional purpose."); State Indus., Inc. v. A.O. Smith Corp., $75^{1}$ F.2d 1226, 1236 (Fed. Cir. 1985) ("One of the benefits of a patent system is its so-called 'negative incentive' to 'design around' a competitor's products, even when they are patented, thus bringing a steady flow of innovations to the marketplace."); Matthew J. Conigliaro et al., Foreseeability in Patent Law, 16 BeRKELEY TECH. L.J. 1045, 1050 \& n.1 7 (2001); Craig Allen Nard, A Theory of Claim Interpretation, 14 HARV. J.L. \& TECH. 1, 40-41 (2000) ("The practice of designing-around extant patents creates viable substitutes and advances, resulting in competition among patented technologies. The public clearly benefits from such activity."). But a design-around is valuable to society only if it generates socially useful new technology. If it is simply an arbitrary change to avoid a patent, the expenditure in designing it is socially wasteful. 
of new product development may involve socially wasteful product changes rather than true innovation.

Figure 5. The Frequency That Patent Licenses from NPEs Led to the Creation of New Products or Features with the Technology Licensed

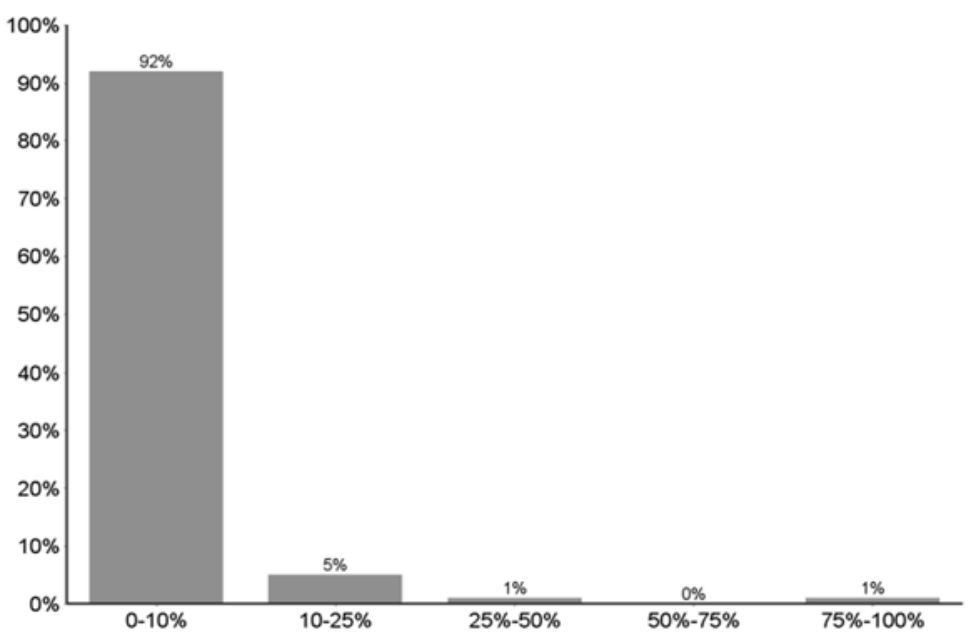

The results were even stronger when respondents were asked about indirect markers of innovation. With almost complete unanimity, respondents who took licenses from NPEs rarely received technical knowledge, transfer of personnel (including consulting agreements), or joint ventures along with the patent license. Thus, when companies licensed patents from NPEs, the indirect markers that might suggest even the potential for future innovation were almost entirely absent.

This result is consistent with the comments we received from survey respondents in the open-ended comment sections. Thus, one respondent wrote: "None of the lawsuits which we settle result in anything other than a pure patent license (i.e., no tech transfer)." Another wrote: "Virtually every license my company has taken has been to ensure freedom of action for products or services we already offer. We have never received any value from a patent license other than to avoid litigation." A third offered the view that NPEs "do not have any of the details worked out and they do not put any capital at risk developing any product, service or market. NPEs simply exact a tax ...." 
Figure 6. The Frequency That NPEs Transferred Technical Knowledge in Addition to the Patent License

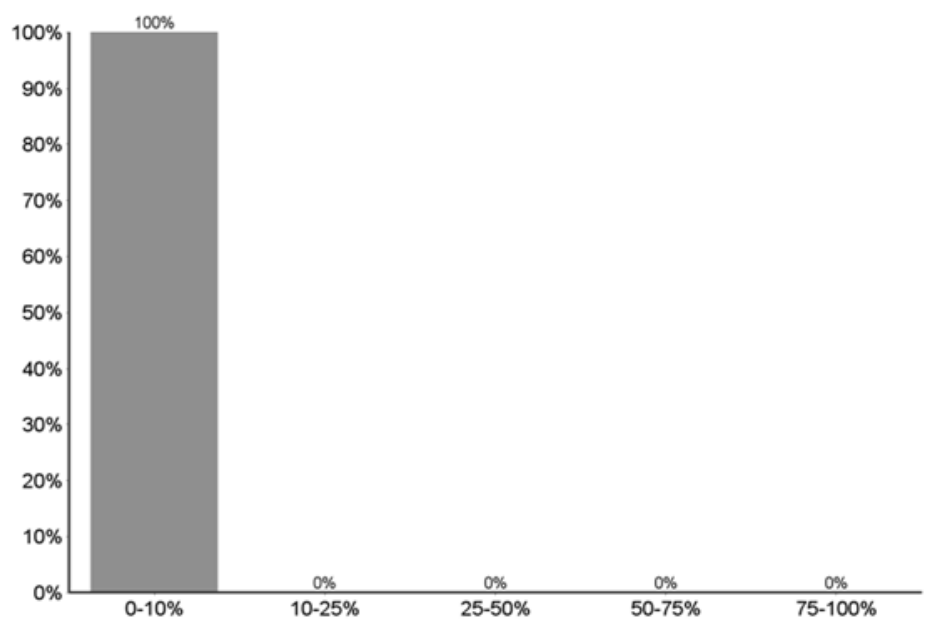

Figure 7. The Frequency That NPEs Transferred Personnel in Addition to the Patent License

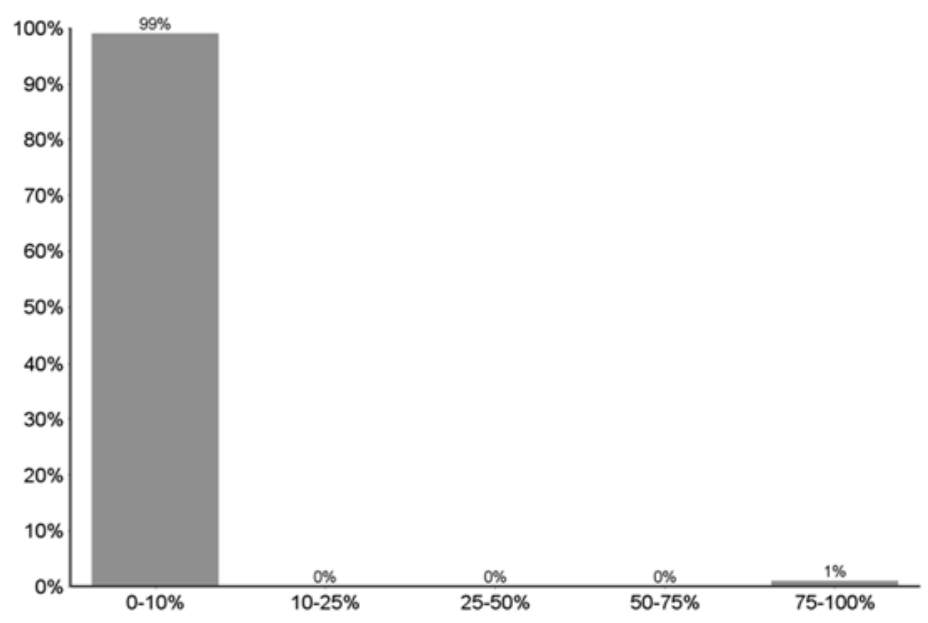


Figure 8. The Frequency That Patent Licenses from NPEs Led to the Creation of a Joint Venture

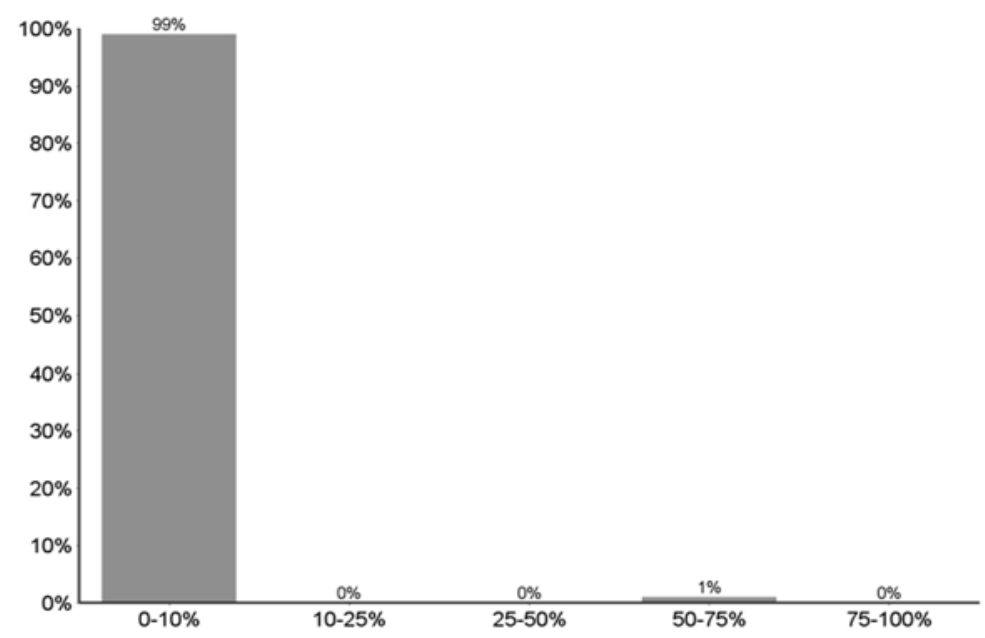

We note, in particular, that the category we are describing as NPEs in our results was described in the survey only as "entities and individuals whose core activity involves licensing or litigating patents." One might have expected that the presence of individuals in this category might have resulted in at least some transfer of knowledge or even consulting agreements, given that such individuals may have been the original inventors of the technology. The knowledge that is so important for translating patents into viable products and features may be lost in the transfer from inventors to entities that aggregate patents, but one would expect that knowledge to exist with the original inventors and that evidence of the sharing of such knowledge would emerge along with the patent license. Our results suggest this is not the case. It is certainly possible that respondents did not properly understand the question and answered only with entities in mind, rather than individuals. The fact that respondents were lawyers and most likely patent lawyers, however, might argue against such a lack of precision in responding to the questions. A more likely explanation is that because NPEs often enforce patents relatively late in their life $4^{2}$ they often approach licensing targets well after the technology has been independently developed and implemented.43 Indeed, in fast moving fields like computers, the four to five years it takes a

42. Love, supra note $3^{6}$, at 1331-32 (showing that most NPE suits are filed near the end of a patent's 20-year life, while most practicing entity suits are filed near the beginning).

43. Cotropia \& Lemley, supra note 13 , at 1424 (finding that over $90 \%$ of patent suits filed against independent inventors and $98 \%$ in the IT industries do not involve any allegations of copying). 
patent to issue 44 means that by the time there is a patent to be licensed the technology is most likely obsolete. 45

2. University and Practicing Entity Licenses Rarely Generate Technology Transfer

The most striking information that emerged from the survey, however, was the following: while NPE licenses were extremely unlikely to lead to new products or be accompanied by other markers of innovation, ex post licensing demands from practicing entities and universities were also unlikely to generate technology transfer. In other words, patentee requests for patent licenses or settlements led to remarkably few markers of innovation regardless of the type of party that initiated the request. In particular, roughly threequarters of respondents answered that when requests for a license or settlement led to a licensing agreement from these categories of patent holders, the technology they licensed led to new products or services zero to ten percent of the time. This was true in the case of competitors, product companies that were not competitors, and even universities.

Figure 9. The Frequency That Patent Licenses from Competitors Led to the Creation of New Products or Features with the Technology Licensed

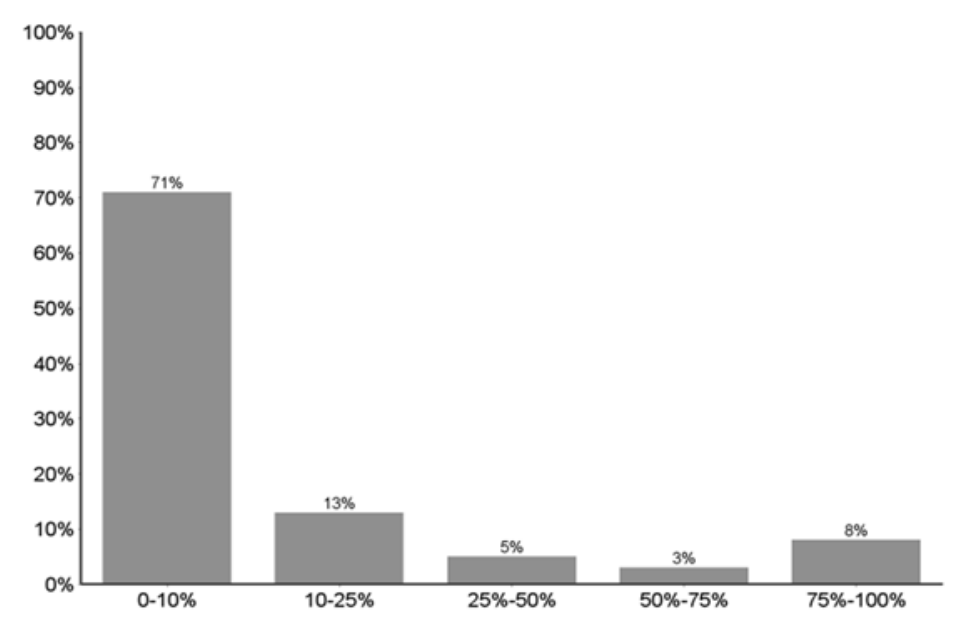

44. Dennis Crouch, Total Patent Application Pendency, PATENTLY-O (Mar. 18, 2012), http:// www.patentlyo.com/patent/2012/o3/total-patent-application-pendency.html (noting that the "average and median total pendency is just under five years"). The number has increased over the past 15 years; in 1998 the average delay was 2.77 years. John R. Allison \& Mark A. Lemley, Who's Patenting What? An Empirical Exploration of Patent Prosecution, 53 VAND. L. REV. 2099, 2118 (2000).

45. For a discussion of the potential implications for the innovation system in rewarding in the case of independent invention, see supra text accompanying notes 6-18. 
Figure 10. The Frequency That Patent Licenses from Product Companies That Were Not Competitors Led to the Creation of New Products or Features with the Technology Licensed

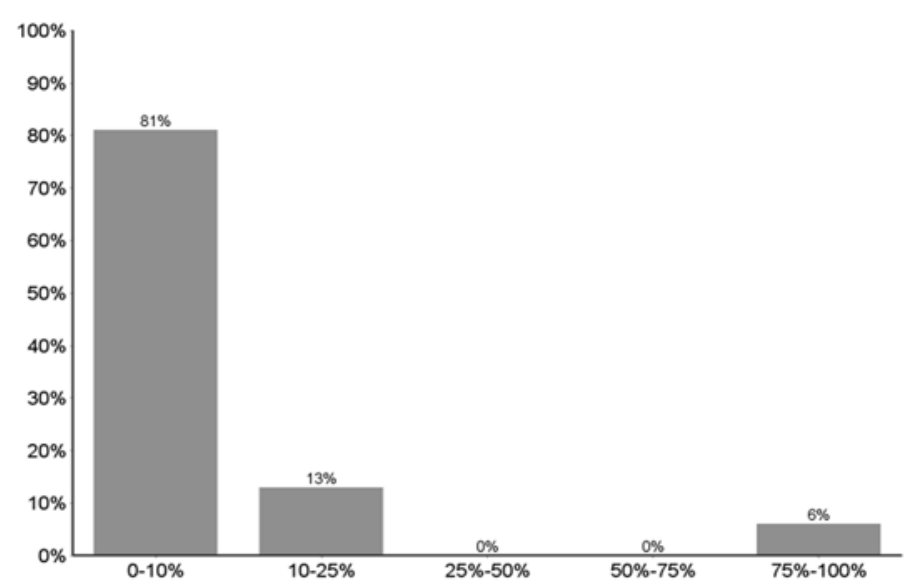

Figure 11. The Frequency That Patent Licenses from Universities Led to the Creation of New Products or Features with the Technology Licensed

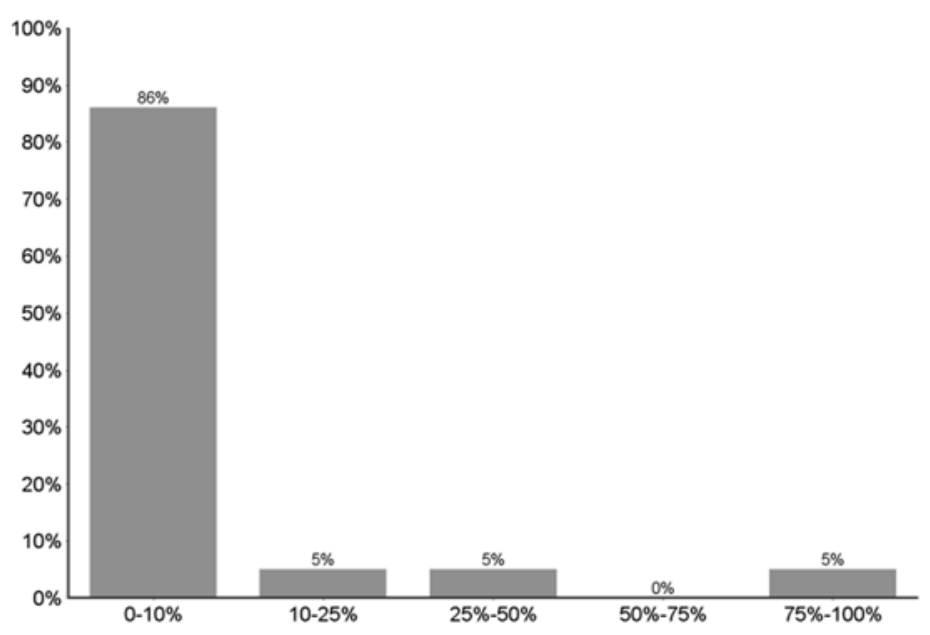

The results were even more dismal for the indirect markers of innovation. When requests for licenses and settlements led to licenses, companies rarely received technical knowledge, transfer of personnel (including consulting agreements), or joint ventures. When requests from 
competitors, product-producing companies that were not competitors, or universities led to patent licenses, $88 \%$ or more of respondents reported that the patent holder transferred knowledge, in addition to the license, zero to ten percent of the time.

Figure 12. The Frequency That Competitors Transferred Technical Knowledge in Addition to the Patent License

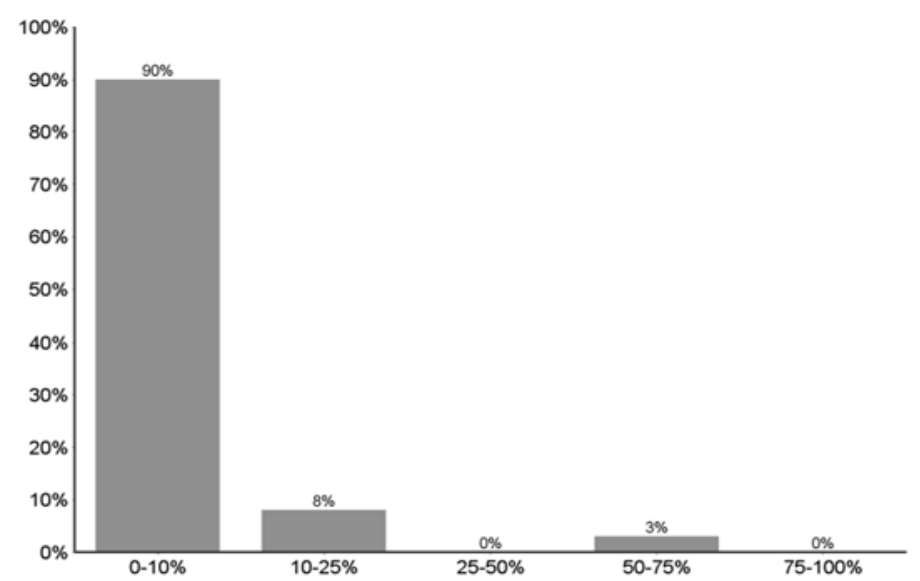

Figure 13. The Frequency That Product-Producing Companies That Were Not Competitors Transferred Technical Knowledge in Addition to the Patent License

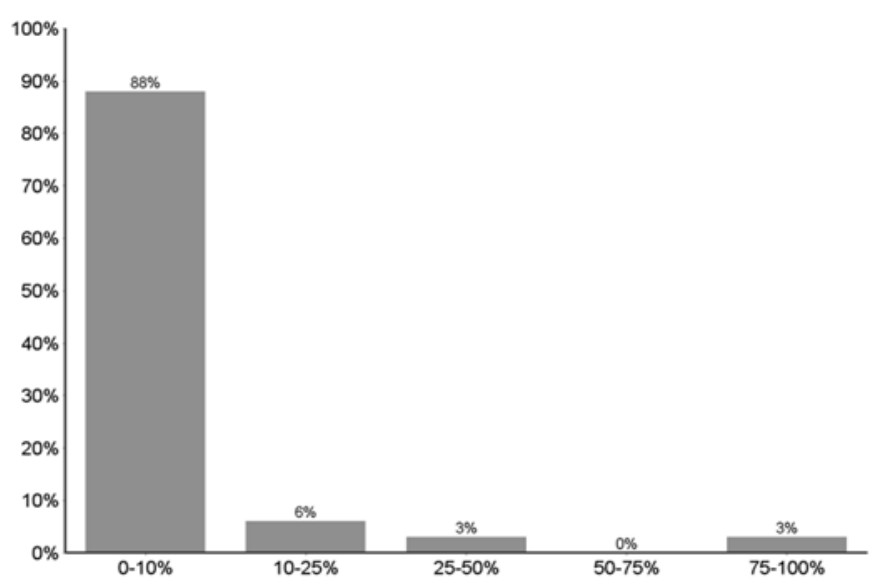


Figure 14. The Frequency That Universities Transferred Technical Knowledge in Addition to the Patent License

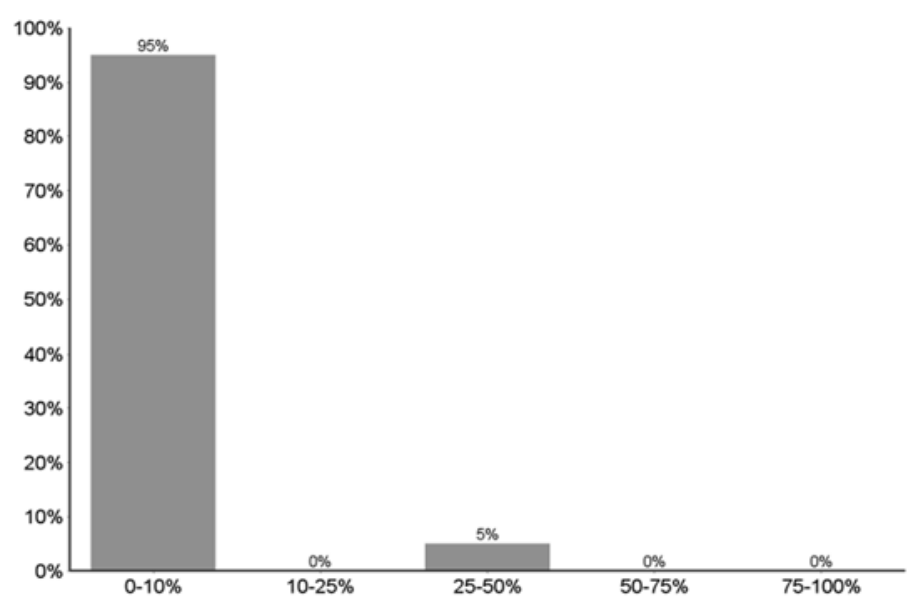

In addition, when requests from competitors, product-producing companies that were not competitors, or universities led to patent licenses, $94 \%$ or more of respondents reported that the patent holder transferred personnel (including through consulting agreements) zero to ten percent of the time.

Figure 15 . The Frequency That Competitors Transferred Personnel in Addition to the Patent License

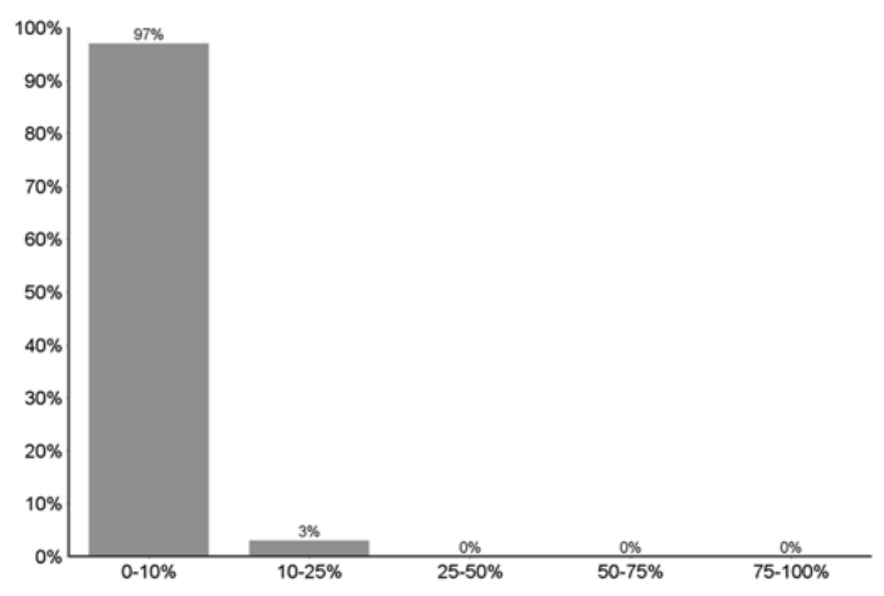


Figure 16. The Frequency That Product-Producing Companies That Were Not Competitors Transferred Personnel in Addition to the Patent License

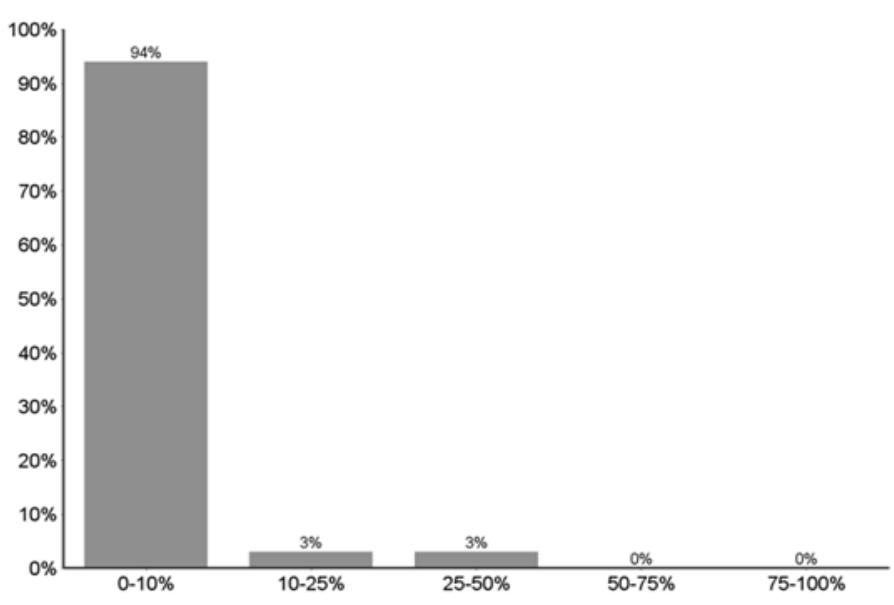

Figure 17. The Frequency That Universities Transferred Personnel in Addition to the Patent License

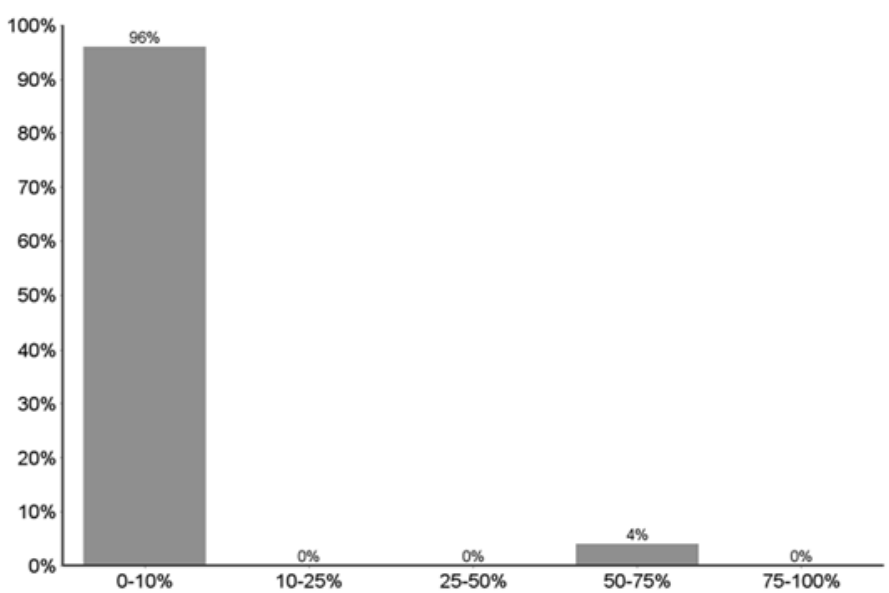

Finally, when requests from competitors, product-producing companies that were not competitors, or universities led to patent licenses, joint ventures were even less likely. Ninety-one percent or more of respondents reported that the patent holder created a joint venture zero to ten percent of the time. In the case of universities, $100 \%$ of respondents reported zero to ten percent joint ventures. 
Figure 18. The Frequency That Patent Licenses from Competitors Led to the Creation of a Joint Venture

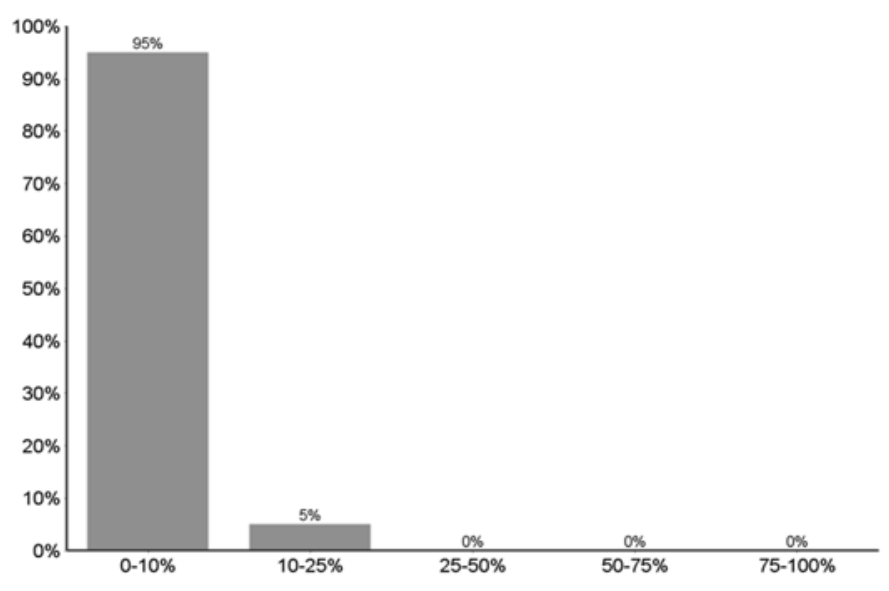

Figure 19. The Frequency That Patent Licenses from Product-Producing Companies That Were Not Competitors Led to the Creation of a Joint Venture

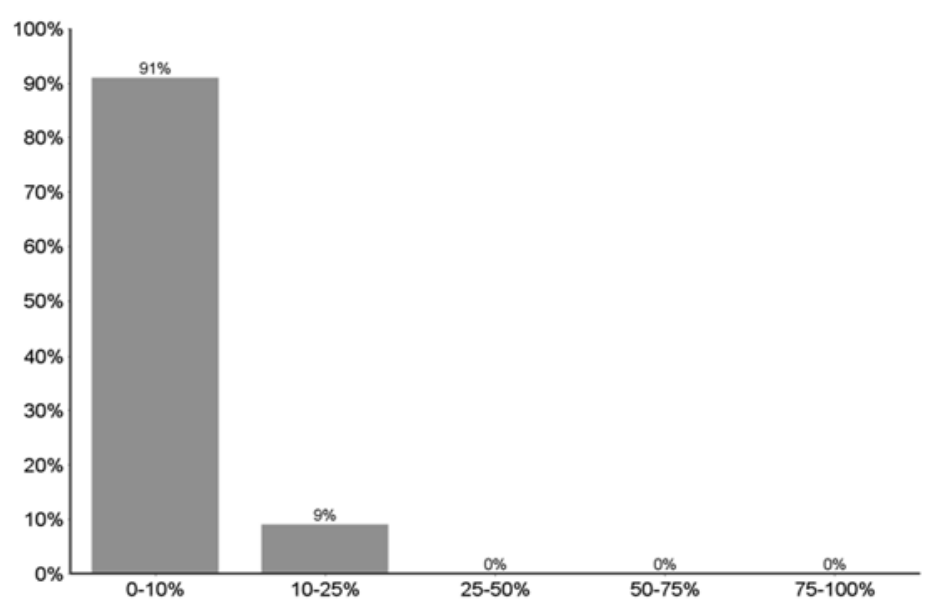


Figure 20. The Frequency That Patent Licenses from Universities Led to the Creation of a Joint Venture

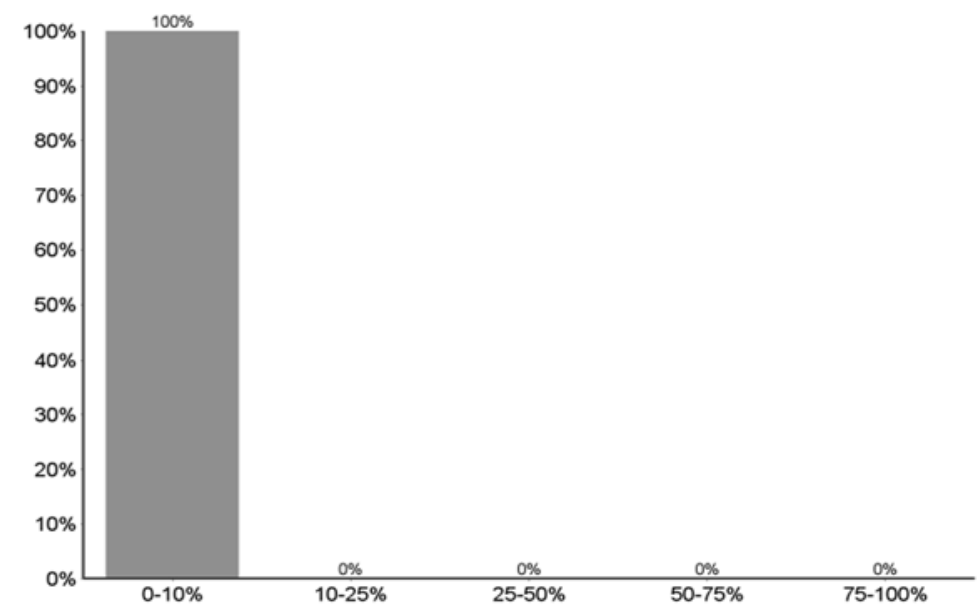

The university results were particularly surprising. Given the storehouse of knowledge in university minds, one would expect such licenses to be particularly fruitful for future innovation at companies. That certainly may be true when companies initiate contact themselves by seeking out university technology. And it may be true when universities or university professors set out to market a new technology rather than a patent license. When universities initiated the contact through licensing requests, however, indirect markers of innovation were largely absent. Little, if any, transfer of knowledge or transfer of personnel occurred, including consulting agreements, nor were joint ventures created. $4^{6}$

\section{TECHNOLOGY TRANSFER AND LICENSING BY INDUSTRY}

In the discussions of modern patent licensing requests, much ink has been spilled about whether the experience of the technology industry is different from the experience of the life sciences. 47 In order to explore this question, we compared the results of surveys from key industry respondents.

46. This is consistent with anecdotal reports that university licensing is increasingly about freedom to operate rather than actual technology transfer. Lemley, supra note 28 , at 615 ("Time and again, when I talk to people in a variety of industries, their view is that universities are the new patent trolls. One even referred publicly to universities as 'crack addicts' driven by 'smallminded tech transfer offices' addicted to patent royalties.").

47. See, e.g., Robin Feldman \& W. Nicholson Price II, Patent Trolling: Why Bio E̋ Pharmaceuticals Are at Risk, 17 STAN. TECH. L. REV. 773, 785-808 (2014) (describing and refuting conventional wisdom that the biopharmaceutical industry is safe from patent trolling). See generally BESSEN \& MEURER, supra note 4; BURK \& LEMLEY, supra note 27. 
Specifically, we compared the responses of those in the Computer \& Other Electronics industry who had received requests for licensing or settlements, to the responses of those in the Pharmaceutical, Biotechnology, and Medical Devices, Methods \& Other Medical groups (collectively referred to as "Life Sciences"). The Computer \& Other Electronics industry group accounted for $20 \%$ of the respondents, and the combined Life Science group accounted for $14 \%$ of the respondents. Given that the number of respondents in these categories is far smaller than the number of respondents for the full data set, we list the actual numbers as well as the percentages for each area described below, in the interests of transparency, and we note that any observations should be tempered by the small sample size.

Respondents were asked to describe the type of party that initiated the licensing or settlement request and the percentage that came from each type of entity. As described above, not all respondents who provided information about the type of party who initiated the request also provided a percentage. In particular, only 6o respondents provided a percentage. Those numbers become quite small in the specified categories. Thus, only seven respondents each volunteered percentage information in the Computer and Life Science categories. Of these, more Computer respondents reported receiving a majority of requests from NPEs than did Life Science respondents-four for Computer versus two for Life Sciences. These numbers, however, are far too small to draw even reliable inferences.

Slightly more information can be gleaned from looking at the full set of respondents who identified the type of party that had initiated any licensing or settlement requests at all, even those who did not go on to specify a percentage from each. From this larger group, 15 of 19 Computer respondents $(79 \%)$ indicated that they had received at least one request from an NPE, while only 6 of 14 of Life Science respondents (43\%) indicated that they had received at least one request from an NPE.

Respondents in both the Computer categories and the Life Science categories were strikingly united in their experiences when taking a license from entities and individuals whose core activity involves licensing or litigating patents. Both categories reported that new products or features were rare. In fact, $100 \%$ of respondents in both the Computer and Other Electronics category and the combined Life Sciences category reported that when licensing or settlement requests led to licenses, the technology they licensed resulted in adding new products or features zero to ten percent of the time. That is 15 out of 15 for Computer respondents and six out of six for Life Science respondents. 
Figure 21. The Frequency That Patent Licenses from NPEs Led to the Creation of New Products or Features with the Technology Licensed, According to Respondents in the Computer Industry

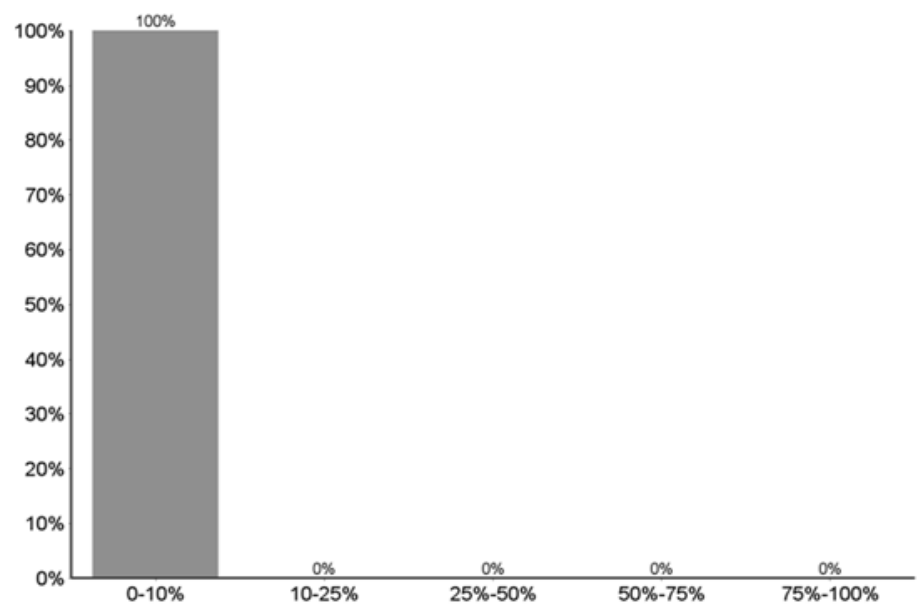

Figure 22. The Frequency That Patent Licenses from NPEs Led to the Creation of New Products or Features with the Technology Licensed, According to Respondents in the Life Sciences Industry

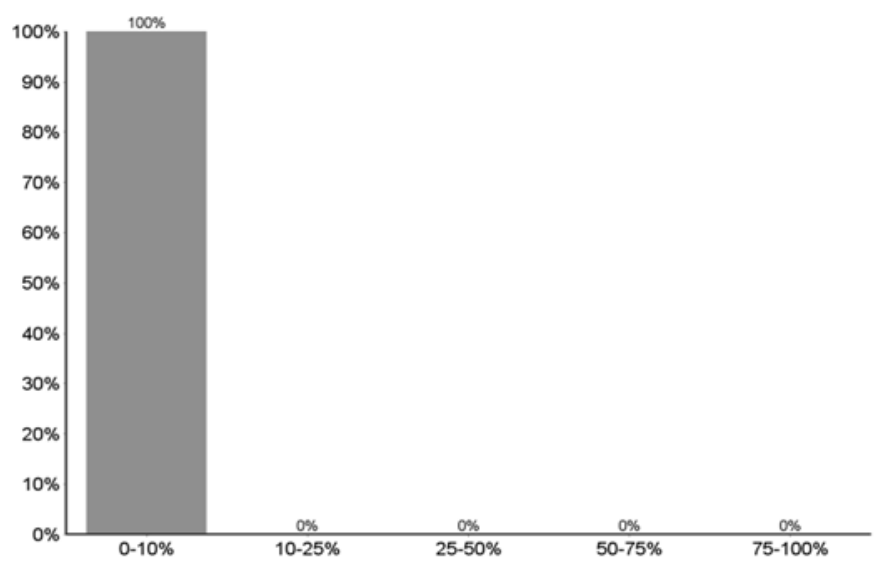

The response was precisely the same for the Computer and Life Sciences categories on the question of whether such licenses led to indirect markers of innovation-knowledge transfer, transfer of personnel (including consulting agreements), or the establishment of joint ventures. Again for both the Computer and Life Science categories, $100 \%$ of respondents reported that 
licensing or settlement requests from NPEs that led to licenses, knowledge transfer, transfer of personnel, or the establishment of joint ventures occurred zero to ten percent of the time.

Figure 23. The Frequency That NPEs Transferred Technical Knowledge in Addition to the Patent License, According to Respondents in the Computer Industry

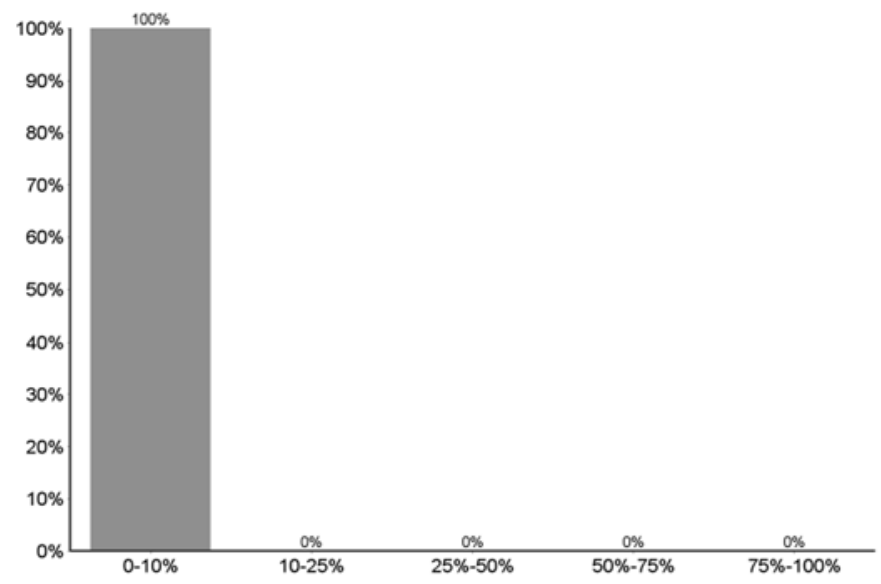

Figure 24. The Frequency That NPEs Transferred Technical Knowledge in Addition to the Patent License, According to Respondents in the Life Sciences Industry

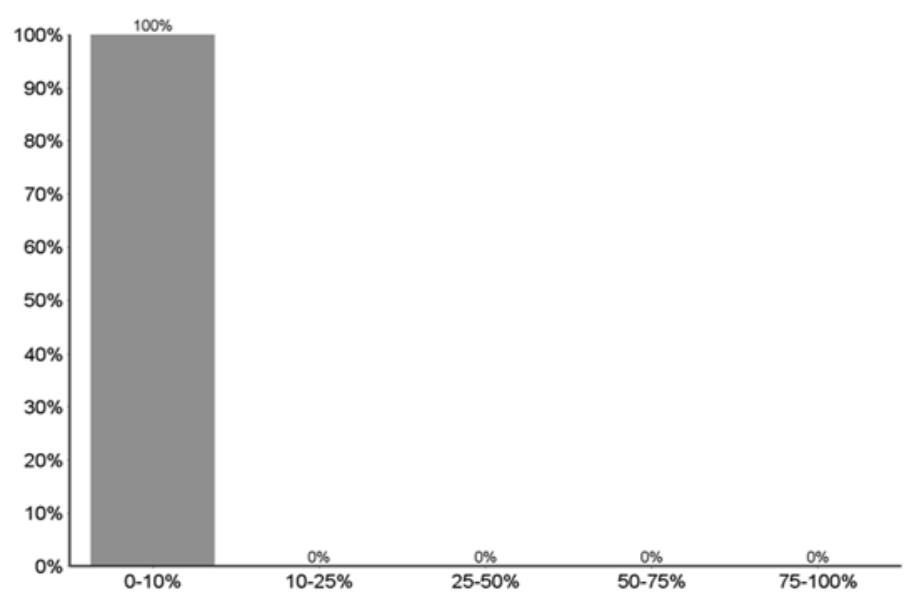


Figure 25. The Frequency That NPEs Transferred Personnel in Addition to the Patent License, According to Respondents in the Computer Industry

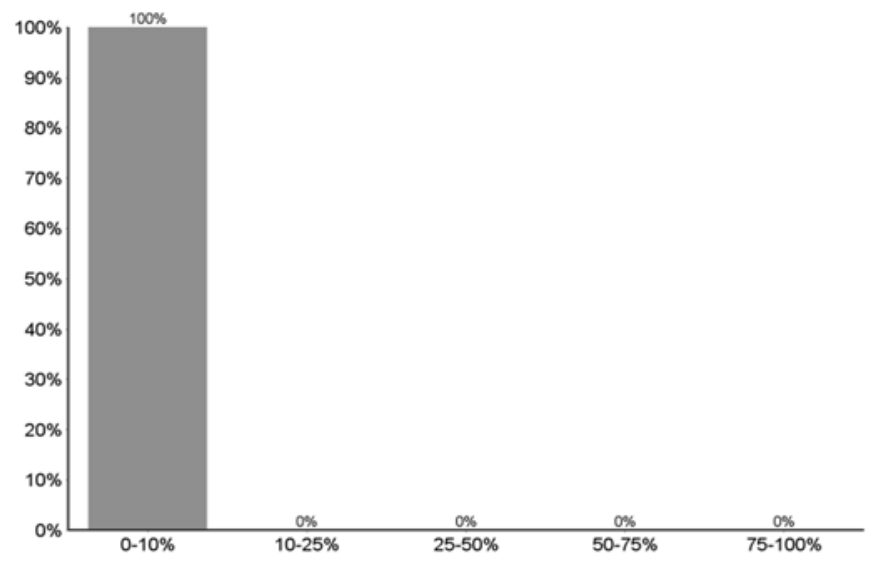

Figure 26. The Frequency That NPEs Transferred Personnel in Addition to the Patent License, According to Respondents in the Life Sciences Industry

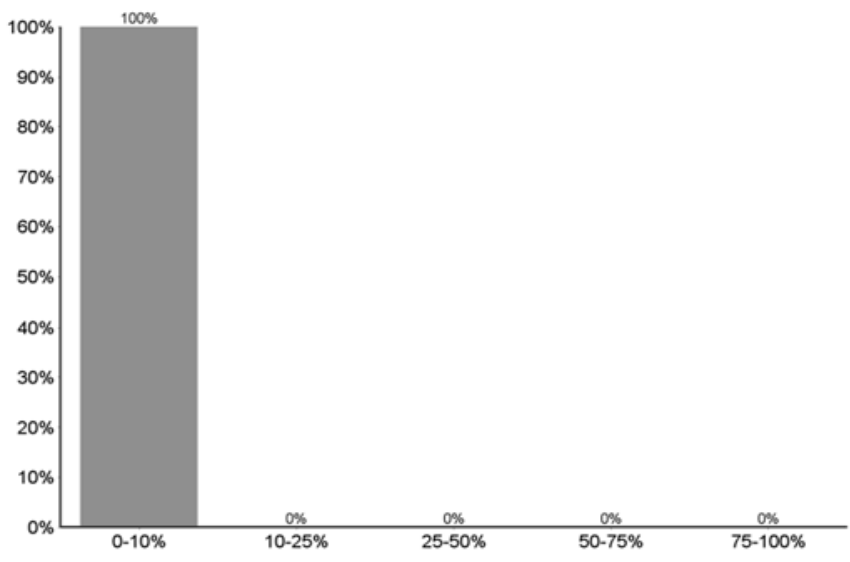


Figure 27. The Frequency That Patent Licenses from NPEs Led to the Creation of a Joint Venture, According to Respondents in the Computer Industry

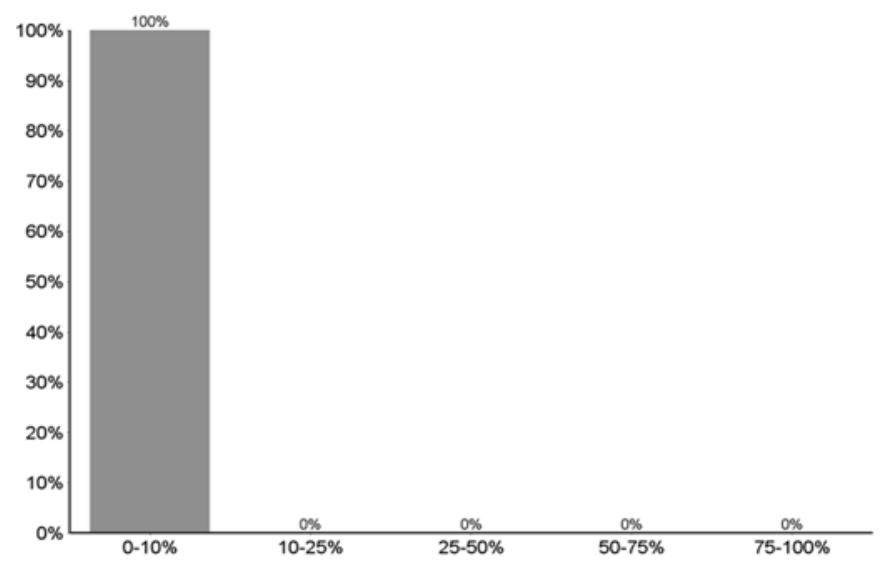

Figure 28. The Frequency That Patent Licenses from NPEs Led to the Creation of a Joint Venture, According to Respondents in the Life Sciences Industry

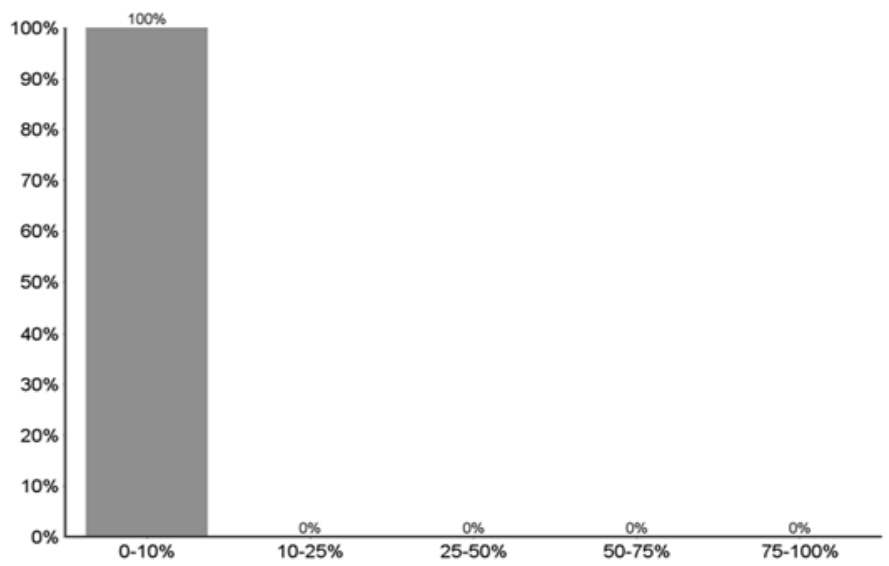

Looking at the addition of new products or features for licenses from competitors, product-producing companies, and universities, the amount of direct innovation is still discouraging, although slightly better than all respondents as a whole. No fewer than two-thirds of respondents in the Computer and Life Science categories reported that licenses led to the addition of new products or features in zero to ten percent of the casesregardless of whether the requests came from competitors, product- 
producing companies who were not competitors, or universities. The comparable number for all respondents as a whole was roughly three-quarters in each category. $4^{8}$

On the question of new products or services, the answers were similar for respondents in the Computer and Life Science industries when requests came from competitors. Four out of six Computer respondents reported new products or services zero to ten percent of the time, while six out of nine Life Science competitors reported new products or services zero to ten percent of the time. With product-producing companies that were not competitors, two out of three Life Science respondents added new products or features zero to ten percent of the time. Nine of nine Computer respondents added new products or services zero to ten percent of the time after taking a license from product-producing companies that were not competitors.

When universities sought licenses, eight of nine Life Science companies added new products and services only zero to ten percent of the time. Similarly, two of three Computer companies added new products or services zero to ten percent of the time when universities sought licenses and the company took a license.

The indirect markers of innovation were still discouraging, although slightly better for some markers of the Life Science category than in the Computer category. The most discouraging results can be seen for licenses when the request came from universities and the companies took a license. In almost every category of indirect markers for both the Life Science and Computer industries, $100 \%$ of respondents reported indirect markers of innovation only zero to ten percent of the time. This included transfer of knowledge, transfer of personnel (including consulting agreements), and the creation of joint ventures. For these categories, there were nine Life Science respondents and three Computer respondents. The only variation from this picture was one Computer respondent who reported transfers of technical knowledge $25 \%$ to $50 \%$ of the time.

In the case of indirect markers of innovation for licenses from competitors, respondents in the Life Sciences industry reported slightly better experiences than for respondents from the Computer industry. Nevertheless, the Life Sciences numbers still show that markers of innovation were rare in most licenses from competitors among respondents.

The same holds true for indirect markers of innovation in the Life Sciences industry for licenses from product-producing companies that are not competitors. Again, the numbers are better for the four Life Science respondents than for the nine Computer respondents.

In short, answers from respondents in the Life Sciences industry and the Computer industry were similar, on the whole. Both direct and indirect

48. Again, the number of respondents in each of these categories was quite small, ranging from three to nine respondents. 
markers of innovation are scarce. In the case of licenses from NPEs, respondents in the Life Sciences and the Computer science industries reported strikingly similar experiences. For both industry groups, $100 \%$ of respondents reported few, if any, direct or indirect markers of innovation when they took licenses from NPEs. Given the many discussions of dissimilarities between the Computer and Life Sciences industry, 49 we found this result surprising, although we note, again, the small number of respondents in these subcategories, which makes generalization risky.

\section{IMPLICATIONS}

Based on our very preliminary evidence, the theory that NPEs facilitate innovation via patent license demands either through the creation of new products or by delivering actual technical know-how from inventors to implementers does not seem to hold water. Our survey responses showed that NPEs almost never actually provided any valuable information to their licensees, and they rarely, if ever, prompted the development of any new products. Licensees in our survey are paying for freedom to operate-the right not to be sued for implementing technology they developed on their own but which someone has asserted will fit within their patent rights. $5^{\circ}$ Thus, the study does not support the efficient middleman hypothesis for characterizing the role of NPEs.

We do not find this particularly surprising. It is consistent with our personal experience with NPE licensing and litigation. It is also consistent with prior evidence that suggests that, outside the pharmaceutical industry, those targeted in patent lawsuits are almost always independent inventors rather than companies accused of copying from the patent owner. $5^{1}$ And it makes perfect sense given the long delays at the Patent and Trademark Office and the fact that NPEs tend to assert their patents late in their life, after the defendant's technology has proven successful. $5^{2}$ The combination of those two factors means that when a company receives a licensing demand from an NPE, it is likely for a patent based on old technology. Indeed, in fast-moving technologies like computers and telecommunications the patent is often on a technology that bears little resemblance to the defendant's product; the NPE

49. See supra note 47 .

5o. While there is strong evidence that almost all defendants in most industries are independent inventors, not copiers, we cannot exclude the possibility that while our respondents did not obtain technology or know-how directly from the patentee, they learned the technology through indirect channels that ultimately trace back to the patentee. See generally Robert P. Merges, A Few Kind Words for Absolute Infringement Liability in Patent Law (Univ. of Cal., Berkeley Sch. of Law Working Paper, 2014) http://papers.ssrn.com/sol3/papers.cfm?abstract_id=2464756 (making this point). While we are skeptical that this happens often with NPEs, our data do not allow us to address the question directly.

$5^{1}$. Cotropia et al., supra note 2 , at 655 .

$5^{2}$. Love, supra note 36 , at 1312 . 
asserts that the patent covers any means of solving a problem, even if the defendant's implementation looks nothing like the patentee's original idea.53

More surprising to us are our findings that neither practicing entities nor even companies in the life sciences do much more technology transfer along with their patent licensing activity. While both practicing entities and life sciences companies in particular engaged in more technology transfer to our survey respondents than NPEs, our results suggest that the modal license signed by those companies is not part of a deal that communicates any knowhow or drives new innovation, but is merely a payment for freedom from a patent lawsuit.

That result, if generalizable, suggests that ex post patent demands are not serving much of an innovation promotion function at all, even in the industries in which we would expect significant technology transfer.54 That does not mean technology transfer never happens; it does. 55 But it may mean that technology transfer happens early in the life of a technology, and that secrets, collaborations, and informal know-how, not patents, are the primary focus of real technology licensing agreements. Patents (or, more likely, patent applications) may well be part of those technology transfer deals, and ownership of patent rights may even be a goal of the deal, but the deal is not being driven by the desire to take a patent license.

The results are also surprising in regard to universities. In the 1980 BayhDole Act, Congress allowed universities to elect ownership of inventions funded by federal dollars and to take on the responsibility for licensing those inventions..$^{6}$ University academics, at least in high-tech industries, are not generally motivated to invent by the prospect of patents.57 The most compelling justification for that major policy shift was that for some types of inventions, exclusive rights are necessary for commercialization and that universities would be in the best position to facilitate that licensing. Such licensing and commercialization would, in theory, lead to the introduction of

53. See, e.g., Lemley, supra note 11 , at $95^{1-5} 5^{2}$.

54. For a discussion of the lack of strong empirical evidence that patents are driving innovation, see generally Stuart Macdonald, When Means Become Ends: Considering the Impact of Patent Strategy on Innovation, 16 INFO. ECON. \& POL'Y 135 (2004); Simone Rose, Further Reflections on Extinguishing the Fountainhead of Knowledge: A Call to Transition to the "Innovation Policy" Narrative in Patent Law, 66 SMU L. REV. 609 (2013).

55. ARORA ET AL., supra note 40, at 93-95.

56. Bayh-Dole Act, Pub. L. No. $9^{6-5^{17}}, 94$ Stat. 3018 (1980) (codified as amended at 35 U.S.C. $\$ \$ 200-212(2012))$.

57. See, e.g., Love, supra note 18 , at 286 ("The prospect of obtaining patent rights to the fruits of their research does not appear to motivate university researchers in high-tech fields to conduct more or better research. ... University patent programs may, instead, actually reduce the quantity and quality of university research ....”). 
new products, thereby giving society a benefit from the federal dollars spent on research..$^{8}$

Our results cast some doubt on the validity of this logic in the case of certain types of university activity. In particular, our results suggest that some universities are approaching product companies, not to create joint ventures or promote the creation of new products, but to seek ex post licenses for already commercialized technology. If a company is willing to commercialize under a nonexclusive license, or no license at all, this casts doubt on some of the logic underpinning Bayh-Dole and on the role that the federal government is expecting universities to play.59 This does not mean universities are not engaged in technology transfer; surely they are. Universities generate a large number of new inventions, and they spin out companies that make innovative new products. ${ }^{60}$ But patent licensing may only be incidental to that transfer, as university scholars start companies or take their ideas to existing companies. In most such cases the start-up or acquiring company is interested in buying the technology, perhaps including buying the patents, not simply in taking a nonexclusive license to those patents. The more recent university practice of suing or demanding licenses from existing companies appears much less likely to be driving innovation by or technology transfer to the recipient of the license demand.

We do not think our data suggest that patents serve no useful purpose. The classic justification for patents, after all, is not to encourage technology transfer but to allow practicing entities to exclude competitors from the marketplace. ${ }^{61}$ Our evidence casts no doubt on that justification. And the hope of future patents may spur innovation that does become the subject of technology transfer. Venture capitalists ("VCs") may view the ability to sell patents as a sort of consolation prize, allowing them to capture some value from failed start-ups. ${ }^{62}$ The VCs in one study vigorously disagreed, however,

58. For discussions of the rationales for Bayh-Dole and some of their criticisms, see, for example, DAVID C. MOWERY ET AL., IVORYTOWER AND INDUSTRIAL INNOVATION: UNIVERSITY-INDUSTRY TECHNOLOGY TRANSFER BEFORE AND AFTER THE BAYH-DOLE ACT 85-98 (2004); Lorelei Ritchie de Larena, The Price of Progress: Are Universities Adding to the Cost?, 43 Hous. L. REV. 1373,1412 (2007); Lemley, supra note 28; Katherine J. Strandburg, Curiosity-Driven Research and University Technology Transfer, in UNIVERSITY ENTREPRENEURSHIP AND TECHNOLOGY TRANSFER: PROCESS, Design, AND InTellectual Property 93 (Gary D. Libecap ed., 2005); John Allison et al., University Software Ownership: Trends, Determinants, Issues (Sept. 2005) (unpublished manuscript), https://law.wustl.edu/clieg/documents/ipconfo5/lausanne.version.pdf.

59. See Ian Ayres \& Lisa Larrimore Ouellette, Ex Ante March-In Rights: A Market Test for Bayh-Dole Patents (unpublished manuscript) (on file with authors).

6o. For estimates of university patent licensing revenue, see, for example, sources cited in Lemley, supra note 28 , at 614 n.10.

61. Lemley, supra note 8, at 993-96.

62. See generally Mark A. Lemley, Reconceiving Patents in the Age of Venture Capital, 4J. SMALL \& EMERGING BUS. L. 137 (2000). For a somewhat skeptical discussion of this possibility, see Maria Leonor Cabanelas \& Chaitanya Ramachandran, The Secondary Market in Patents: Help or Hindrance for Start-Ups?, InTELl. Asset MGMT., March/April 2015, at 79. But any such benefit comes at a 
with one VC explaining, "VCs swing for the fences; they are not interested in pennies on the dollar." ${ }_{3}$ Further, Michael Risch has argued that we may need the threat of troll suits to induce product-producing companies to transact with NPEs who can actually transfer technology rather than stealing that technology from them. ${ }^{6}{ }_{4}$ As Jessica Silbey has observed, patents can serve a variety of functions. ${ }^{65}$ We do not intend a full assessment of all of them here.

But NPEs, universities, and practicing companies that are licensing patents in areas in which they are not practicing cannot defend their assertion of patents on the ground that they are excluding competitors from the marketplace and therefore recouping additional investment. If their licensing of patents is contributing to social welfare, it must be because it encourages either innovation or the dissemination of information that would not otherwise be available to the world. And the evidence from our survey results suggests that some of the commonly asserted ways in which patents might encourage innovation-by facilitating new products or technology transferare not borne out.

Companies are increasingly spending significant amounts of time, resources, and creative energy responding to ex post patent assertion both inside and outside of litigation. Our results suggest that this vast amount of activity is largely unproductive, no matter who initiates it - an NPE, a product company or a university. Ex post licensing may be promoting transactions, but not necessarily economically efficient transactions. ${ }^{66}$

cost to the next generation of start-ups, who may face demands from the trolls who bought the last generation. Id. See generally Chien, supra note 23.

63. See Feldman, supra note 23 , at 278-79 (noting that $65 \%$ of venture capitalists in a survey disagreed with the following statement: "[A]s a venture capitalist, in making funding decisions, I consider the potential for selling patents to patent assertion entities if the companies fail").

64. Risch, supra note 7, at 10o6-1 2; see also Haber \& Werfel, supra note 16, at 2-4, 19-2o.

65. See generally Jessica Silbey, Patent Variation: Discerning Diversity Among Patent Functions, 45 LOY. U. CHI. L.J. 441 (2013).

66. As Rob Merges explains: "[T] here is also a problem with the argument that all trolls are just market makers and hence beneficial to economic activity. Not all arbitrage exchange is in fact efficient and socially desirable." Robert P. Merges, The Trouble with Trolls: Innovation, RentSeeking, and Patent Law Reform, 24 BERKELEY TECH. L.J. 1583, 1588 (2009); see also Michael J. Burstein, Patent Markets: A Framework for Evaluation (Working Paper, 2015), http:/ / papers.ssrn. $\mathrm{com} / \mathrm{sol}_{3} /$ papers.cfm?abstract_id=2590375 (questioning when transactions in patent rights are socially productive).

Notably, the conclusion that these transactions are unproductive holds even if the patents in question are valid and infringed. This is a set of assumptions that has been called into question by a number of scholars. For descriptions of how the NPE business model can generate returns when patents are invalid or improperly asserted, see Robin Feldman, Intellectual Property Wrongs, 18 STAN. J.L. BuS. \& Fin. 250, 261-63 (2013). See generally Bessen \& Meurer, supra note 17 ; Ewing \& Feldman, supra note 4 ; Lemley \& Shapiro, supra note 41 ; Morton \& Shapiro, supra note 17. 
But before we conclude that the patent system is not working, or that it is working only for practicing entities that want to exclude their competitors from the market, we should gather more data. Our survey is limited, both in the number of respondents and because of its low response rate. There may be other, underrepresented sectors of the economy in which patent-based technology transfer is significant. Or we may have found an unrepresentative subset of technology companies to survey. We also note that even within the panoply of patent licensing, we have examined only certain aspects. For example, our study did not examine the licensing that occurs when a product company initiates the approach to a patent holder seeking new technology. Nor does it study the substantial cross-licensing activity taking place between competitors. ${ }^{67}$ And it does not cover sales of patents. Our intent is to follow up with a more comprehensive survey in the near future. In the meantime, our data offer the first ever window into the role of patent licensing in facilitating technology transfer and the development of new technologies by the licensee. And the preliminary picture is not an encouraging one.

67. For a discussion of the economics of that cross-licensing, see, for example, Lemley \& Melamed, supra note 1, at 2129-46; Gideon Parchomovsky \& R. Polk Wagner, Patent Portfolios, 154 U. PA. L. REV. 1 , 73-74 (2005). 
APPENDIX A

\begin{tabular}{|c|c|}
\hline INDUSTRY SECTOR & HOOVER'S INDUSTRIES \\
\hline $\begin{array}{l}\text { Computer \& Other } \\
\text { Electronics }\end{array}$ & $\begin{array}{l}\text { Computer Hardware Manufacturing } \\
\text { Education \& Training Software } \\
\text { Contract Electronics Manufacturing } \\
\text { Engineering, Scientific \& CAD/CAM Software } \\
\text { Networking \& Connectivity Software } \\
\text { Security Software } \\
\text { Wireless Software } \\
\text { Audio \& Video Equipment Manufacturing } \\
\text { Consumer Electronics Manufacturing } \\
\text { Electronic Toys \& Games Manufacturing } \\
\text { Electronic Equipment Repair Services } \\
\text { Gaming Equipment Manufacturing } \\
\text { Consumer Electronics \& Appliances Stores } \\
\text { Electronic Component Manufacturing }\end{array}$ \\
\hline Semiconductor & $\begin{array}{l}\text { Semiconductor Equipment Manufacturing } \\
\text { Semiconductor Manufacturing } \\
\text { Discrete \& Passive Semiconductor Manufacturing } \\
\text { Semiconductor \& Other Electronic Component } \\
\quad \text { Manufacturing }\end{array}$ \\
\hline Pharmaceutical & $\begin{array}{l}\text { Pharmaceutical Manufacturing } \\
\text { Drug Stores }\end{array}$ \\
\hline $\begin{array}{l}\text { Medical Devices, } \\
\text { Methods \& Other } \\
\text { Medical }\end{array}$ & $\begin{array}{l}\text { Health Care Products Manufacturing } \\
\text { HVAC Equipment Manufacturing } \\
\text { Health Care Management Software }\end{array}$ \\
\hline Biotechnology & $\begin{array}{l}\text { Biotechnology Product Manufacturing } \\
\text { Scientific Research \& Development Services } \\
\text { Biotechnology Research Services } \\
\text { Biotechnology Research Equipment Manufacturing }\end{array}$ \\
\hline Communications & $\begin{array}{l}\text { Telecommunications Equipment Manufacturing } \\
\text { Telecommunications Services }\end{array}$ \\
\hline Transportation & $\begin{array}{l}\text { Transportation Equipment Manufacturing } \\
\text { Transportation Services Sector }\end{array}$ \\
\hline Construction & $\begin{array}{l}\text { Construction Sector } \\
\text { Construction Machinery Manufacturing }\end{array}$ \\
\hline Energy & $\begin{array}{l}\text { Electric Power Generation } \\
\text { Electric Power Transmission, Distribution \& Marketing } \\
\text { Electric Utilities } \\
\text { Natural Gas Distribution \& Marketing } \\
\text { Oil \& Gas Exploration \& Production } \\
\text { Oil \& Gas Field Services } \\
\text { Oil \& Gas Well Drilling } \\
\text { Petroleum \& Coal Products Manufacturing } \\
\end{array}$ \\
\hline
\end{tabular}




\begin{tabular}{|l|l|}
\hline & Business Services Sector \\
& Chemical Manufacturing \\
& Accounting \& Finance Software \\
& Business Intelligence Software \\
& Database \& File Management Software \\
Development Tools, Operating Systems \& Utilities & \multicolumn{1}{|c|}{ Software } \\
Goods \& Services for & E-commerce Software \\
Industrial \& Business & Manufacturing, Warehousing \& Industrial Software \\
& Security Software \\
& Manufacturing Sector \\
& Wholesale Sector \\
& Geophysical Surveying \& Mapping Services \\
& Information Technology Services \\
& Testing Laboratories \\
\hline \multirow{3}{*}{ Goods \& Services for } & Arts, Entertainment \& Recreation Sector \\
Consumer Uses & Consumer Products Manufacturing \\
& Consumer Services \\
& Retail Sector \\
\hline
\end{tabular}




\section{APPENDIX B}

Q1 In the last five years, has your company received patent licensing or settlement requests? (These could be calls or letters suggesting areas of mutual interest or joint ventures, offering to license patents, threatening litigation, giving notice of intent to file an infringement lawsuit, or noticing the filing of an actual infringement lawsuit.)

$\begin{array}{ll}\text { o } & \text { Yes } \\ 0 & \text { No }\end{array}$

Q2 On average over the past five years, how often has your company received patent licensing or settlement requests?

o Less than once a year

$0 \quad 1-5$ times per year

o 6-10 times per year

o $11-5$ o times per year

o More than $5^{\text {o times per year }}$

Q3 What parties initiated these requests (approximate percentage for each category)?

o Competitors

o Product-producing companies that are not competitors

o Entities or individuals whose core activity involves licensing or litigating patents

o Universities

o Nature of the party was unclear

$\mathrm{Q}_{4}$ What percentage of competitor requests led your company to take a patent license, whether or not a lawsuit was ultimately filed?
o $0-10 \%$
$0 \quad 10-25 \%$
$0 \quad 25-50 \%$
o $5^{\mathrm{O}-75 \%}$
o $75^{-100 \%}$

$Q_{5}$ When competitor requests led to a patent license, how often was a lawsuit filed prior to reaching the licensing agreement?

$0 \quad 0-10 \%$ lawsuit filed first

o $10-25 \%$ lawsuit filed first

o $\quad 25-50 \%$ lawsuit filed first

o $55^{\mathrm{O}-75 \%}$ lawsuit filed first

o $75^{-100 \%}$ lawsuit filed first 
Q6 When competitor requests led to a patent license, how often did you create new products or features with the technology you licensed (e.g., as opposed to merely taking the license to cover existing products or features)?
o $0-10 \%$
$0 \quad 10-25 \%$
$0 \quad 25-50 \%$
0 5 - $-75 \%$
0 $75^{-100 \%}$

Q7 When competitor requests led to a patent license, how often did the competitor transfer technical knowledge in addition to the patent license?
$0 \quad 0-10 \%$
$0 \quad 10-25 \%$
$0 \quad 25-50 \%$
o $5^{\mathrm{O}-75 \%}$
0 $75^{-100 \%}$

Q8 When competitor requests led to a patent license, how often did the competitor transfer personnel in addition to the patent license (e.g., through a consulting agreement)?
$0 \quad 0-10 \%$
$0 \quad 10-25 \%$
$0 \quad 25-50 \%$
o $5^{\mathrm{O}-75 \%}$
0 $75^{-100 \%}$

Q9 When competitor requests led to a patent license, how often was a joint venture created in conjunction with the patent licensing?
$0 \quad 0-10 \%$
$0 \quad 10-25 \%$
$0 \quad 25-50 \%$
o $5^{\mathrm{O}-75 \%}$
o $75^{-100 \%}$

Q10 What percentage of requests from product producing companies (that are not competitors) led your company to take a patent license, whether or not a lawsuit was ultimately filed?
$0 \quad 0-10 \%$
$0 \quad 10-25 \%$
$0 \quad 25-50 \%$
o $5^{\mathrm{O}-75 \%}$
o $75^{-100 \%}$ 
Q11 When requests from product producing companies (that are not competitors) led to a patent license, how often was a lawsuit filed prior to reaching the licensing agreement?
$0 \quad 0-10 \%$ lawsuit filed first
$0 \quad 10-25 \%$ lawsuit filed first
$0 \quad 25-50 \%$ lawsuit filed first
o $55^{\mathrm{O}-75 \%}$ lawsuit filed first
o $75^{-100 \%}$ lawsuit filed first

Q12 When requests from product producing companies (that are not competitors) led to a patent license, how often did you create new products or features with the technology you licensed (e.g., as opposed to merely taking the license to cover existing products or features)?
o $0-10 \%$
$0 \quad 10-25 \%$
$0 \quad 25-50 \%$
0 $55^{\mathrm{O}-75 \%}$
o $75^{-100 \%}$

Q13 When requests from product producing companies (that are not competitors) led to a patent license, how often did the product producing company (that is not a competitor) transfer technical knowledge in addition to the patent license?
o $0-10 \%$
$0 \quad 10-25 \%$
$0 \quad 25-50 \%$
o $5^{\mathrm{O}-75 \%}$
o $75^{-100 \%}$

Q14 When requests from product producing companies (that are not competitors) led to a patent license, how often did the product producing company (that is not a competitor) transfer personnel in addition to the patent license (e.g., through a consulting agreement)?
o $0-10 \%$
o $10-25 \%$
o $25-50 \%$
o $5^{\mathrm{O}-75 \%}$
○ $75^{-100 \%}$ 
Q15 When requests from product producing companies (that are not competitors) led to a patent license, how often was a joint venture created in conjunction with the patent licensing?
$0 \quad 0-10 \%$
$0 \quad 10-25 \%$
$0 \quad 25-50 \%$
o $55^{\mathrm{O}-75 \%}$
0 $75^{-100 \%}$

Q16 What percentage of requests from entities or individuals whose core activity involves licensing or litigating patents led your company to take a patent license, whether or not a lawsuit was ultimately filed?
$0 \quad 0-10 \%$
$0 \quad 10-25 \%$
$0 \quad 25-50 \%$
o $55^{\mathrm{O}-75 \%}$
0 $75^{-100 \%}$

Q17 When requests from entities or individuals whose core activity involves licensing or litigating patents led to a patent license, how often was a lawsuit filed prior to reaching the licensing agreement?
$0 \quad 0-10 \%$ lawsuit filed first
$0 \quad 10-25 \%$ lawsuit filed first
o $25-50 \%$ lawsuit filed first
o $55^{\mathrm{O}-75 \%}$ lawsuit filed first
o $75^{-100 \%}$ lawsuit filed first

Q18 When requests from entities or individuals whose core activity involves licensing or litigating patents led to a patent license, how often did you create new products or features with the technology you licensed (e.g., as opposed to merely taking the license to cover existing products or features)?
o $0-10 \%$
$0 \quad 10-25 \%$
o $25-50 \%$
o $55^{\mathrm{O}-75 \%}$
0 $75^{-100 \%}$ 
Q19 When requests from entities or individuals whose core activity involves licensing or litigating patents led to a patent license, how often did the entity or individual whose core activity involves licensing or litigating patents transfer technical knowledge in addition to the patent license?
o $0-10 \%$
$0 \quad 10-25 \%$
$0 \quad 25-50 \%$
0 $55^{\mathrm{O}-75 \%}$
o $75^{-100 \%}$

Q20 When requests from entities or individuals whose core activity involves licensing or litigating patents led to a patent license, how often did the entity or individual whose core activity involves licensing or litigating patents transfer personnel in addition to the patent license (e.g., through a consulting agreement)?
o $0-10 \%$
O $10-25 \%$
o $25-50 \%$
o $5^{\mathrm{O}-75 \%}$
0 $75^{-100 \%}$

Q21 When requests from entities or individuals whose core activity involves licensing or litigating patents led to a patent license, how often was a joint venture created in conjunction with the patent licensing?
o $0-10 \%$
$0 \quad 10-25 \%$
$0 \quad 25-50 \%$
o $5^{\mathrm{O}-75 \%}$
0 $75^{-100 \%}$

Q22 What percentage of requests from universities led your company to take a patent license, whether or not a lawsuit was ultimately filed?
o $\quad 0-10 \%$
o $10-25 \%$
o $25-50 \%$
o $5^{\mathrm{O}-75 \%}$
o $75^{-100 \%}$ 
Q23 When requests from universities led to a patent license, how often was a lawsuit filed prior to reaching the licensing agreement?
$0 \quad 0-10 \%$ lawsuit filed first
$0 \quad 10-25 \%$ lawsuit filed first
$0 \quad 25-50 \%$ lawsuit filed first

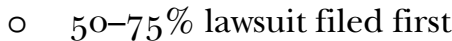
o $\quad 75^{-100 \%}$ lawsuit filed first

Q24 When requests from universities led to a patent license, how often did you create new products or features with the technology you licensed (e.g., as opposed to merely taking the license to cover existing products or features)?
$0 \quad 0-10 \%$
$0 \quad 10-25 \%$
$0 \quad 25-50 \%$
o $55^{\mathrm{O}-75 \%}$
0 $75^{-100 \%}$

Q25 When requests from universities led to a patent license, how often did the university transfer technical knowledge in addition to the patent license?
$0 \quad 0-10 \%$
$0 \quad 10-25 \%$
$0 \quad 25-50 \%$
o $55^{\mathrm{O}-75 \%}$
0 $75^{-100 \%}$

Q26 When requests from universities led to a patent license, how often did the university transfer personnel in addition to the patent license (e.g., through a consulting agreement)?
$0 \quad 0-10 \%$
$0 \quad 10-25 \%$
$0 \quad 25-50 \%$
0 5 - $-75 \%$
0 $75^{-100 \%}$

Q27 When requests from universities led to a patent license, how often was a joint venture created in conjunction with the patent licensing?
$0 \quad 0-10 \%$
$0 \quad 10-25 \%$
$0 \quad 25-50 \%$
o $5^{\mathrm{O}-75 \%}$
0 $75^{-100 \%}$ 
Q28 What percentage of requests from parties whose nature was unclear led your company to take a patent license, whether or not a lawsuit was ultimately filed?
$0 \quad 0-10 \%$
$0 \quad 10-25 \%$
$0 \quad 25-50 \%$
0 $55^{\mathrm{O}-75 \%}$
0 $75^{-100 \%}$

Q29 When requests from parties whose nature was unclear led to a patent license, how often was a lawsuit filed prior to reaching the licensing agreement?
$0 \quad 0-10 \%$ lawsuit filed first
o $10-25 \%$ lawsuit filed first
o $25-50 \%$ lawsuit filed first
o $5 \mathrm{O}-75 \%$ lawsuit filed first
o $75^{-100 \%}$ lawsuit filed first

Q3o When requests from parties whose nature was unclear led to a patent license, how often did you create new products or features with the technology you licensed (e.g., as opposed to merely taking the license to cover existing products or features)?
$0 \quad 0-10 \%$
$0 \quad 10-25 \%$
$0 \quad 25-50 \%$
o $55^{\mathrm{O}-75 \%}$
0 $75^{-100 \%}$

Q31 When requests from parties whose nature was unclear led to a patent license, how often did the party whose nature was unclear transfer technical knowledge in addition to the patent license?
o $0-10 \%$
o $10-25 \%$
$0 \quad 25-50 \%$
o $55^{\mathrm{O}-75 \%}$
o $75^{-100 \%}$ 
Q32 When requests from parties whose nature was unclear led to a patent license, how often did the party whose nature was unclear transfer personnel in addition to the patent license (e.g., through a consulting agreement)?
$0 \quad 0-10 \%$
$0 \quad 10-25 \%$
$0 \quad 25-50 \%$
0 $55^{\mathrm{O}-75 \%}$
0 $75^{-100 \%}$

Q33 When requests from parties whose nature was unclear led to a patent license, how often was a joint venture created in conjunction with the patent licensing?
$0 \quad 0-10 \%$
$0 \quad 10-25 \%$
o $25-50 \%$
0 $55^{\mathrm{O}-75 \%}$
0 $75^{-100 \%}$

Q34 Where is your company headquartered?
o Alabama
o Alaska
o Arizona
o Arkansas
o California (No.)
o California (So.)
o Colorado
o Connecticut
o Delaware
o District of Columbia
o Florida
o Georgia
o Hawaii
o Idaho
o Illinois
o Indiana
o Iowa
o Kansas
o Kentucky
o Louisiana
o Maine
o Maryland
o Massachusetts
o Michigan 

o Minnesota
o Mississippi
o Missouri
o Montana
o Nebraska
o Nevada
o New Hampshire
o New Jersey
o New Mexico
o New York
o North Carolina
o North Dakota
o Ohio
o Oklahoma
o Oregon
o Pennsylvania
o Rhode Island
o South Carolina
o South Dakota
o Tennessee
o Texas
o Utah
o Vermont
o Virginia
o Washington
o West Virginia
o Wisconsin
o Wyoming

Q35 What is your company's annual revenue?
o $\$ 0-\$ 5$ Million
$0 \quad \$ 5$ Million-\$10 Million
o $\$ 10$ Million- $\$ 5$ o Million
o $\$ 5$ o Million-\$1 oo Million
o \$1 oo Million +

Q36 What is your company's primary business sector?

o Computer \& Other Electronics

o Semiconductor

o Pharmaceutical

o Medical Devices, Methods, \& Other Medical

o Biotechnology

o Communications

o Transportation 
o Construction

o Energy

o Goods \& Services for Industrial \& Business Uses (i.e. goods and services for wholesale uses that are not in another category, including software-implement business method inventions)

o Goods \& Services for Consumer Uses (i.e. goods and services for retail uses that are not in another category, including softwareimplement business inventions)

Q37 Would you be willing to participate in additional research on patent behavior?

O Yes

Q38 Please provide contact information in the box below. (Note: All survey data is anonymous. Contact information will not be associated with individual survey responses.)

Q39 If you would like to elaborate on your answers to any of the questions above, please add your comments here. 